\title{
IT Assets, Organizational Capabilities, and Firm Performance: How Resource Allocations and Organizational Differences Explain Performance Variation
}

\author{
Sinan Aral \\ Massachusetts Institute of Technology Sloan School of Management, and New York University Stern School of Business, \\ 44 West 4th Street, Room 8-81, New York, New York 10012, sinan@stern.nyu.edu \\ Peter Weill \\ Center for Information Systems Research, MIT Sloan School of Management, 3 Cambridge Center, NE20-332, \\ Cambridge, Massachusetts 02142, pweill@mit.edu
}

\begin{abstract}
$\mathrm{D}$ espite evidence of a positive relationship between information technology (IT) investments and firm performance, results still vary across firms and performance measures. We explore two organizational explanations for this variation: differences in firms' IT investment allocations and their IT capabilities. We develop a theoretical model of IT resources, defined as the combination of specific IT assets and organizational IT capabilities. We argue that investments into different IT assets are guided by firms' strategies (e.g., cost leadership or innovation) and deliver value along performance dimensions consistent with their strategic purpose. We hypothesize that firms derive additional value per IT dollar through a mutually reinforcing system of organizational IT capabilities built on complementary practices and competencies. Empirically, we test the impact of IT assets, IT capabilities, and their combination on four dimensions of firm performance: market valuation, profitability, cost, and innovation. Our results-based on data on IT investment allocations and IT capabilities in 147 U.S. firms from 1999 to 2002-demonstrate that IT investment allocations and organizational IT capabilities drive differences in firm performance. Firms' total IT investment is not associated with performance, but investments in specific IT assets explain performance differences along dimensions consistent with their strategic purpose. In addition, a system of organizational IT capabilities strengthens the performance effects of IT assets and broadens their impact beyond their intended purpose. The results help explain variance in returns to IT capital across firms and expand our understanding of alignment between IT and organizations. We illustrate our findings with examples from a case study of 7-Eleven Japan.
\end{abstract}

Key words: business value of information technology; information technology assets; resource-based theory; complementarities; IT infrastructure; IT capabilities; IT practices; firm performance

\section{Introduction}

For more than a decade, research has attempted to untangle the relationship between information technology (IT), productivity, and organizational performance. Early results uncovered a "paradox" in the relationship (Loveman 1994, Strassman 1990) that has subsequently been explained by both substantive and methodological considerations (Bakos 1991, Dos Santos et al. 1993, Brynjolfsson and Hitt 1996). Recently, more precise measurements have demonstrated a convincing (albeit varied) positive relationship among IT investments, economic productivity, and business value across distinct measures (Brynjolfsson and Hitt 1996, Dewan and Min 1997, Bharadwaj et al. 1999). Although this research provides evidence of a general relationship between IT and organizational performance, our knowledge of the specific factors driving these general results remains quite limited. In this paper we address two important questions that remain unanswered.

First, returns to IT investments exhibit substantial variation across firms. Large sample statistical evidence demonstrates that nearly half of the productivity benefits originally attributed to IT capital can be more accurately explained by firm-specific factors (e.g., Brynjolfsson and Hitt 1995). These results imply the existence of a set of organizational characteristics that are simultaneously and positively correlated with both IT investment and organizational performance. Some firms simply derive greater value per IT dollar even when controlling for industrylevel variation. But what types of organizational characteristics explain this variation? To address this question, we open the black box of the organization to examine what types of organizational factors and management practices contribute to a firm's ability to generate business value from IT.

Second, the majority of firm-level analysis measures IT in the aggregate. As a result, we know little about the relative performance contributions of different types of IT investments and whether different IT investments impact different aspects of firm performance. One explanation for why two firms with the same amount of IT capital perform differently is that they are investing 
in different types of technology with different goals. We therefore conceptualize IT as four distinct types of assets, implemented to achieve different management objectives, and test their relative performance effects.

We explore these questions using data from 147 firms over 4 years and illustrate the results using qualitative evidence from a case study of 7-Eleven Japan. We find that investments in a particular IT asset class deliver higher performance only along dimensions consistent with the strategic purpose of that asset. For example, investments in transactional IT applications, made to reduce costs in standard, repetitive processes, are associated with lower costs but not with more firm-level product innovation. In contrast, investments in strategic IT applications are associated with more product innovation, but not with lower costs. These results suggest that a monolithic view of IT may obscure the importance of resource allocations within the IT function by focusing on the performance implications of firms' total IT capital stock. We also find evidence for complementarities between IT and a system of organizational IT capabilities (ITC). IT investments and organizational ITC covary significantly in our sample, demonstrating that firms high in IT intensity develop IT-related organizational capabilities and that firms with strong IT capabilities demand more IT. Firms with stronger organizational ITC also derive greater value per IT dollar. We find that ITC both strengthens intended performance effects and broadens the impact of investments in particular IT assets beyond their intended performance goals. Our findings demonstrate the importance of pursuing more detailed and disaggregated measures of IT intensity, organizational IT capabilities, and firm performance in IS research.

\section{Theory and Literature}

\subsection{The Resource-Based Theory of the Firm}

Recent research on the relationship between IT and organization describes systems of organizational practices that complement IT. One theoretical perspective that convincingly addresses the complementarity of IT and organizational processes, practices, routines, and activities is the resource-based theory of the firm (Wernerfelt 1984, Barney 1991). This theory argues that durable competitive advantage emerges from unique combinations of resources (Grant 1996) that are economically valuable, scarce, and difficult to imitate (Barney 1991). As these resources are imperfectly mobile across firm boundaries and because firms pursue different strategies in deploying these resources, they are likely to be heterogeneously distributed across firms. Firm resources are insulated from competitive imitation by path dependencies, embeddedness, casual ambiguity about the source of competitive advantage, and time diseconomies of imitation (Barney
1991, Mata et al. 1995). These heterogeneously distributed and difficult-to-imitate resources in part drive differences in firm performance.

From this perspective, there are compelling theoretical reasons for investigating how firms allocate investments across different types of IT assets. The resource-based view separates stocks of undifferentiated factors of production from resources, defined as the combination of firm-specific assets (Wernerfelt 1984) and organizational capabilities (Richardson 1972, Nelson and Winter 1982, Dosi et al. 2000). The dynamic capabilities framework (Teece et al. 1997), which extends the resource-based view to incorporate environmental and technological change, stresses the importance of tangible and intangible "specific asset positions" in shaping firm resources. Teece et al. (1997, pp. 522-523) argue that "a firm's previous investments and repertoire of routines constrain its future behavior;" and that "opportunities for learning will be 'close in' to previous activities and thus will be transaction and production specific." Taken together, these theoretical treatments of resources, assets, and capabilities imply that firms invest in particular types of resources and learn how to use those resources over time by developing asset-specific skills and accompanying routines (Cohen and Levinthal 1990). Resources are difficult to imitate in part because firms are unaware of their competitors' resource allocations and how they contribute to performance (causal ambiguity) and because capability development and learning opportunities are tied to firms' specific asset positions (path dependencies) (Dierickx and Cool 1989). If learning and behavior inside firms are shaped by specific asset positions, then firms that spend more heavily on particular assets should display abnormally higher performance in measures that reflect the goals of those assets as they learn how to deploy them with complementary organizational processes. We argue that investment allocations and organizational differences help shape the heterogeneous IT resources firms develop and explain variation in firm performance. We empirically distinguish assets, defined as investments in different types of IT, from capabilities, defined as practices and competencies that support the use of IT.

\subsection{The Resource-Based Theory of IT}

Although the resource-based view provides a helpful theoretical perspective from which to evaluate the heterogeneity of firm performance, the existing IT literature suffers from ambiguity in the definition and conceptualization of IT resources (Wade and Hulland 2004). Most current conceptualizations of IT resources equate potentially heterogeneous investment allocations across firms by measuring total IT intensity. Some empirically confound resources with capabilities by not measuring both investments and organizational factors simultaneously. Others theoretically distinguish IT infrastructure from 
nontechnical assets (such as human capital and external relationships) but do not distinguish them empirically or measure firms' specific dollar investments in different types of IT assets (Ross et al. 1996, Bharadwaj 2000). Of the perspectives reviewed by Wade and Hulland (2004) that distinguish different IT resources, none identifies the strategic purpose of the resource for the firm and none measures investments in different types of IT assets, implicitly discounting the possibility that investment allocations help shape firms' IT resources and performance.

Organizational capabilities moderate the relationship between IT investments and different measures of firm performance (e.g., Brynjolfsson and Yang 1997, Bharadwaj 2000), but aggregate measures of IT investment and ambiguous definitions of IT resources produce varied results. For example, Zhu and Kraemer (2002) identify four metrics that assess the e-commerce capability of firms and demonstrate that firms with greater e-commerce capabilities perform better on some dimensions of performance (e.g., supply chain optimization) but perform worse along other dimensions (e.g., the cost of goods sold). These results provide convincing evidence of complementarities between an aggregate measure of IT intensity and organizational capabilities in e-commerce. However, the aggregate measure of IT intensity also reveals some surprising results. The authors argue that inexperience and high learning costs may explain the surprising result that "the use of e-commerce, together with IT investment, is associated with increased COGS for traditional manufacturing companies" (Zhu and Kraemer 2002, p. 288). At the same time, they acknowledge that their data "did not capture enough details of the differences in the nature of [e-commerce capabilities] and IT resources between [firms]" to test whether different types of IT resources are driving performance differences (Zhu and Kraemer 2002 , p. 288). An alternative explanation for this surprising result is that traditional manufacturing firms are investing in fundamentally different IT resources than the high-tech firms in their second subsample. Modernization of the factory floor and trends toward flexible manufacturing are requiring manufacturing firms to undertake significant investments in new IT infrastructures (Milgrom and Roberts 1990). Prior empirical work (reviewed below) suggests that investments in IT infrastructure may cause short-term disruptions that increase costs relative to other types of IT assets, which could explain why traditional manufacturing firms see higher costs with more IT investment. To test this alternative explanation, more detailed data on how firms allocate aggregate IT investments is necessary. Our aim is to sharpen the theoretical characterization of "IT resources" by unpacking two major sources of variation in the empirical evidence on complementarities between IT and organization: heterogeneity in IT investment allocations and organizational IT capabilities.

\subsection{Reconceptualizing IT Resources as Combinations of IT Assets and IT Capabilities}

In our theoretical model, IT resources are combinations of investment allocations and a mutually reinforcing system of competencies and practices that together represent organizational ITC. Figure 1 depicts our model based on theoretical concepts drawn from reviews of the IT and organizational capabilities literatures and the resource-based theory of the firm, supported by five qualitative case studies conducted in conjunction with our quantitative analysis.

Firms make heterogeneous investment allocations in pursuit of different goals (e.g., cost leadership or innovation), resulting in a varying landscape of IT resources

Figure 1 Theoretical Model of IT Resources

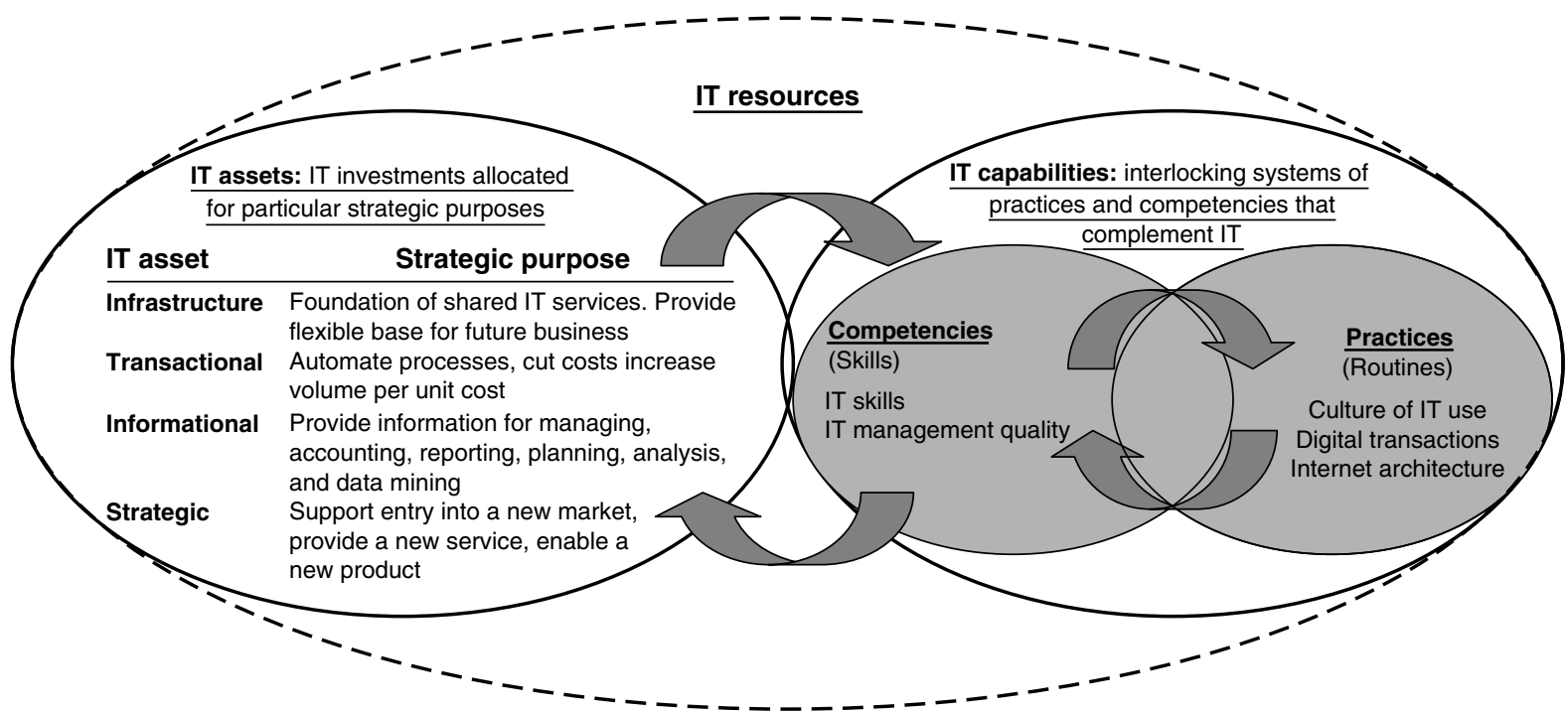


across firms. For example, firms with cost leadership strategies will likely allocate investments toward transactional IT systems designed to cut costs, but firms pursuing innovation strategies will likely invest more in IT systems that support product and process innovation. Strong IT resources are scarce and difficult to imitate because developing effective combinations of IT assets and IT capabilities takes time spent learning and optimizing. This heterogeneity, in both investment allocations and capabilities, drives performance variation across differentiated dimensions that reflect firm strategies. Differentiated investment allocations will enable some firms to cut costs and others to innovate; strong ITC will increase the return per IT dollar invested.

The next two sections present the theoretical development of our framework for measuring IT assets and ITC as the building blocks of IT resources.

\subsection{Disaggregating Total IT Capital into IT Asset Classes}

Most empirical examinations of IT business value consider IT as an aggregate, uniform asset (Bharadwaj et al. 1999), divide IT investments into capital and labor stock (Bynjolfsson and Hitt 1996, Hitt and Brynjolffson 1996, Bharadwaj 2000), or examine particular technologies, such as ATMs or production control technologies (Kelley 1994, Dos Santos and Peffers 1995). Bharadwaj et al. (1999, p. 1020) argue "it appears that firms benefit unequally from their different IT investments. Thus it would be interesting to examine the impact of different types of IT investments such as innovative versus noninnovative, strategic versus nonstrategic, and internally focused (e.g., process control, coordination, etc.) versus externally focused investments (customer satisfaction, relationship management, etc.)...."

Although IT investment allocations are likely to reflect firm strategy and affect firm performance (Floyd and Wooldridge 1990, Dos Santos et al. 1993), few studies disaggregate IT investments by asset type. To address this gap, we apply a framework developed by Weill (1992) and extended by Weill and Broadbent (1998) that categorizes firms' IT investments into a portfolio of four IT assets disaggregated by strategic purpose: infrastructure, transactional, informational, and strategic assets. This framework has been validated and empirically tested in previous work, and we hypothesize that investments in each asset class are associated with gains along performance dimensions consistent with their strategic purpose.

HYPOTHESIS 1. Investments in IT assets are associated with higher firm performance only along dimensions consistent with the strategic purpose of the asset.

We measure IT investment allocations according to how firms' senior managers characterize spending across the four IT asset classes:

1. IT infrastructure provides the foundation of shared IT services (both technical and human-e.g., servers, networks, laptops, shared customer databases, help desk, application development) used by multiple IT applications (Keen 1991, Weill and Broadbent 1998). Infrastructure investments are typically made to provide a flexible base for future business initiatives and thus are made in anticipation of future business needs. The disruptive nature of enterprisewide infrastructure implementations creates high up-front costs and long benefit time horizons (Duncan 1995, Weill and Broadbent 1998). However, infrastructure investments also enable new applications and functionality and lay the groundwork for significant long-term performance improvements (Duncan 1995, Broadbent et al. 1999). We therefore expect that infrastructure investments are positively associated with higher short-term costs, lower short-term profitability, and higher profitability and operational performance in the long run. In addition, if infrastructure investments are transparent to the market, we will likely see a positive impact on firm market value, which reflects the market's assessment of firms' future value.

2. Transactional investments are made to automate processes, cut costs, or increase the volume of business a firm can conduct per unit cost (e.g., order processing, point of sale processing, bank cash withdrawal, billing statement production, insurance renewal, and other repetitive transaction processing functions). We expect transactional investments are associated with immediate cost reductions.

3. Informational investments provide information for managing, accounting, reporting, and communicating internally and with customers, suppliers, and regulators. Examples include decision support, sales analysis, planning, six sigma programs, and Sarbanes-Oxley reporting systems. These investments can support the responsiveness, control, reliability, and adaptability of firms and enable more effective decision making. Sales analysis and data mining of customer reactions to products and services can help optimize products and pricing, thus enabling more efficient and profitable operations. We expect informational investments to tighten reporting and control functions and to improve data collection and decision making, thereby reducing costs and identifying new opportunities for revenue generation and profitability improvements.

4. Strategic investments reposition firms in the marketplace by supporting entry into a new market or the development of new products, services, or business processes. Successful strategic investments typically change the nature of service delivery or organizational processes in an industry, but they become nonstrategic when competitors commoditize the capability. When ATMs were introduced in the banking industry, 
Table 1 IT Assets and Expected Performance Benefits

\begin{tabular}{|c|c|c|}
\hline IT asset & Strategic purpose & $\begin{array}{c}\text { Expected } \\
\text { performance benefits }\end{array}$ \\
\hline Infrastructure & $\begin{array}{l}\text { Foundation of shared } \\
\text { IT services. Provide } \\
\text { flexible base for } \\
\text { future business } \\
\text { initiatives }\end{array}$ & $\begin{array}{l}\text { - Short term: Greater } \\
\text { costs, less profitability } \\
\text { (due to disruption) } \\
\text { - Greater market value } \\
\text { - Long term: Greater } \\
\text { profit, lower costs }\end{array}$ \\
\hline Transactional & $\begin{array}{l}\text { Automate processes, } \\
\text { cut costs, increase } \\
\text { volume of business } \\
\text { per unit cost }\end{array}$ & - Lower costs \\
\hline Informational & $\begin{array}{l}\text { Provide information for } \\
\text { managing, accounting, } \\
\text { reporting, decision } \\
\text { support, planning, } \\
\text { control, analysis, and } \\
\text { data mining }\end{array}$ & $\begin{array}{l}\text { - Lower costs } \\
\text { - Greater profitability }\end{array}$ \\
\hline Strategic & $\begin{array}{l}\text { Support entry into a } \\
\text { new market, provide } \\
\text { a new service, or } \\
\text { enable a new product }\end{array}$ & $\begin{array}{l}\text { - More product } \\
\text { innovation }\end{array}$ \\
\hline
\end{tabular}

they changed the nature of service delivery and garnered competitive benefits for early adopters (Dos Santos and Peffers 1995), but became nonstrategic and transactional as they were universally adopted. We expect strategic investments contribute directly to product innovation (Samabmurthy et al. 2003). Table 1 describes expected performance gains by asset class.

\subsection{IT Capabilities as a Mutually Reinforcing System of Practices and Competencies}

A variety of individual capabilities, practices, and processes may complement IT; however, we expect systems of practices and competencies working in concert to enable greater business value generation per IT dollar. Milgrom and Roberts (1990) formally demonstrate that nonconvexities exist in a firm's decision to adopt any or all of a set of organizational characteristics that together complement new technology. As the marginal benefit of adopting any one of a complementary set of activities increases with the adoption of the others, adoption of systems of practices (what Milgrom and Roberts 1990 call "groups of activities") "may not be marginal decision[s]." They argue, "Exploiting such an extensive system of complementarities requires coordinated action between traditionally separate functions..." (Milgrom and Roberts 1990, p. 515). We use prior research and our own case studies to identify a group of interlocking organizational characteristics that together support firms' ability to derive value from IT. Complementarity theory predicts both the clustering of these IT capabilities and their moderating effects on firm performance. To validate the systematic nature of IT complements, we identify and measure capabilities separately, test the degree to which they covary in our sample, and subsequently examine their performance implications as an interlocking system, or cluster, as depicted in Figure 1.

Although Milgrom and Roberts (1990) adopt a narrow theoretical perspective focused on complementary groups of activities, the conceptualization of organizational complements to IT in theories drawn from evolutionary economics and the resource-based view of the firm take a broader view. These theories address not only the activities organizations engage in, but also the skills and competencies they develop in using assets to accomplish organizational tasks. At least two fundamental conceptual building blocks useful for identifying characteristics of firms that complement IT emerge from these theories: competencies (or skills) and practices (or routines) (Nelson and Winter 1982). Competencies refer to skills embodied in individuals or groups that actively manage or accomplish organizational tasks (Prahalad and Hamel 1990, Dosi et al. 2000). Competencies are developed through learning and the repeated performance of contextual activities. As individuals and groups interact with IT for particular purposes, they learn, build skills, and develop competence toward effective use. Practices, in contrast, refer to recurring sets of activities or routines that serve both as a means of accomplishing organizational tasks and as mechanisms for socially storing and accessing knowledge about the most effective ways to accomplish those tasks (Cohen and Levinthal 1990). Practices and competencies support and complement each other. Practices help individuals and groups develop competence or skill with particular ways of working (Dosi et al. 2000), and skills are necessary for the effective execution of organizational practices toward specified goals (Nelson and Winter 1982).

To develop the construct of organizational ITC we first identified candidate constructs in the literature that were supported by our case evidence. We then developed a coherent conceptualization by excluding elements unrelated to the system of characteristics identified across all cases. We use case studies to inform our construct development and measurement and to illustrate and inform the conclusions we draw from quantitative results. Case studies were conducted in two medium-sized manufacturing firms, one large and one medium-sized financial services firm, and 7-Eleven Japan, a large Japanese retailer (see Weill and Aral 2005, Nagayama and Weill 2004 for published case material). ${ }^{1}$ In this paper, we use illustrative examples exclusively from 7-Eleven Japan to describe distinctions between different IT assets and the systematic and mutually supportive nature of individual competencies and practices in a single organization. We further refined our inclusion and exclusion criteria by testing the degree to which our candidate constructs worked together as a "system," as evidenced by their covariance across firms in our larger sample and the 
Table 2 IT Capability Constructs: Theoretical Development and Examples of Supporting Qualitative Evidence

\begin{tabular}{|c|c|c|}
\hline $\begin{array}{l}\text { IT capability } \\
\text { construct }\end{array}$ & Theoretical justification & $\begin{array}{l}\text { Illustrative examples of qualitative evidence from } \\
\text { 7-Eleven Japan case data }\end{array}$ \\
\hline \multicolumn{3}{|l|}{ Competencies } \\
\hline $\begin{array}{l}\text { Human resource } \\
\text { competency }\end{array}$ & $\begin{array}{l}\text { - Skill-biased technical } \\
\text { change (e.g., Autor } \\
\text { et al. 1998) } \\
\text { - IT-skill complementarity } \\
\text { (e.g., Breshnahan } \\
\text { et al. 2002) }\end{array}$ & $\begin{array}{l}\text { - Immersive training of } 200,000 \text { employees in point of sale data analysis; } \\
\text { including analysis of information on products, weather conditions, regional } \\
\text { demographics, and customer purchasing patterns to improve sales, customer } \\
\text { satisfaction, and ordering. } \\
\text { - Close contact and coaching of store franchisees by company "counselors" } \\
\text { in the use of IT to support decision making. Twice weekly visits by counselors } \\
\text { to stores reinforce practices and support development of skills. }\end{array}$ \\
\hline $\begin{array}{l}\text { Management } \\
\text { competency }\end{array}$ & $\begin{array}{l}\text { - Senior management } \\
\text { championing } \\
\text { (e.g., Weill 1992) } \\
\text { - Alignment of IT and } \\
\text { business units (e.g., } \\
\text { Rockhart et al. 1996) }\end{array}$ & $\begin{array}{l}\text { - Strong commitment of senior management to IT projects and IT-based } \\
\text { processes comes directly from the CEO, who has been committed to } \\
\text { data-based decision making and IT-based communication since } \\
\text { joining 7-Eleven Japan in } 1974 \text {. } \\
\text { Business processes tightly integrated with and enabled by IT decisions. } \\
\text { For a detailed set of examples see Nagayama and Weill (2004), in particular } \\
\text { Exhibit 5. }\end{array}$ \\
\hline \multicolumn{3}{|l|}{ Practices } \\
\hline $\begin{array}{l}\text { IT use intensity for } \\
\text { communication }\end{array}$ & $\begin{array}{l}\text { - Systems-use theory } \\
\text { (e.g., Doll and } \\
\text { Torkzadeh 1998) } \\
\text { - Task-technology fit } \\
\text { theory (e.g., Goodhue } \\
\text { and Thompson 1995) }\end{array}$ & $\begin{array}{l}\text { - "Total Information System" connects } 70,000 \text { computers in stores, at } \\
\text { headquarters, and at supplier sites to facilitate internal and external } \\
\text { communication and coordination. } \\
\text { - Quote-Salesperson of 7-Eleven supplier: "[Their] information system is so } \\
\text { good that we can instantly find out which goods of ours are selling [in their } \\
\text { stores] to what types of customers and how much." } \\
\text { - Quote-7-Eleven executive: "Even if the point of sale data [are] used, } \\
\text { [they] cannot be utilized for the next order unless the hypothesis of } \\
\text { potential demand is shared among all store clerks as well as the store } \\
\text { owner. Therefore, we need to establish a system that enables store owners } \\
\text { and the ordering clerks to create their hypotheses and share them } \\
\text { among part-time workers at the store [even if they cannot communicate } \\
\text { face to face]." }\end{array}$ \\
\hline $\begin{array}{l}\text { Digital transaction } \\
\text { intensity }\end{array}$ & $\begin{array}{l}\text { - Transaction cost theory } \\
\text { (e.g., Williamson 1975) } \\
\text { - Coordination theory } \\
\text { (e.g., Malone et al. 1987) } \\
\text { - Customer intimacy (e.g., } \\
\text { Mithas et al. 2005) }\end{array}$ & $\begin{array}{l}\text { - Digital transactions enable order processing three times per day. Time to } \\
\text { delivery is reduced, orders are organized for use (e.g. by temperature-frozen, } \\
\text { refrigerated, ambient), and costs of order processing are reduced. } \\
\text { - Digital transactions enable tracking and analysis of point of sales data to } \\
\text { inform daily ordering decisions. Each day's data is analyzed for decisions } \\
\text { made the next morning. } \\
\text { - Customer satisfaction goal drives IT-enabled business transactions like "Item } \\
\text { Control" and "Product Supply Management" designed to directly address } \\
\text { customer needs and increase customer convenience. }\end{array}$ \\
\hline Internet architecture & $\begin{array}{l}\text { - e-commerce capability } \\
\text { theory (e.g., Zhu and } \\
\text { Kraemer 2002) }\end{array}$ & $\begin{array}{l}\text { - The Internet shopping site (www.7dream.com, a strategic IT asset) is } \\
\text { integrated with physical stores to offer payment acceptance and } \\
\text { pick-up and/or delivery services for products purchased on line. } \\
\text { - Use of multipurpose, Internet-enabled store copy machines to provide new } \\
\text { services including preordering, printing, and purchasing of airline tickets. } \\
\text { Also see Nagayama and Weill (2004), Exhibit } 10 \text {. }\end{array}$ \\
\hline
\end{tabular}

results of factor analysis conducted using the broader set of 18 factors. Using this process, we identified two competencies and three practices. ${ }^{2}$ Table 2 presents a summary of the five competencies and practices, their theoretical justification, and supportive examples from case data.

2.5.1. Competencies (Skills). Competencies exist across two organizational dimensions in our data: the IT skills of employees at all levels (both technical and business skills) and IT management competence. Shifts in labor demand over the last 25 years favoring more skilled and educated workers have been driven in large part by "skill-biased technical change" or technical progress that shifts demand toward more skilled workers (Autor et al. 1998). Unlike shifts in labor demand during the Industrial Revolution, which favored unskilled factory labor (Goldin and Katz 1998), today's technology complements greater autonomy, flexibility, and skilled employees. A strong empirical relationship between IT use and skill at the worker (Kreuger 1993), firm (Dunne et al. 1997), and industry (Autor et al. 1998) levels demonstrates that firms with significant amounts of IT tend to hire more skilled workers. But few studies examine the performance implications of the copresence of IT and highly skilled labor (for an exception, 
Table 3 Variable Definition and Descriptive Statistics

\begin{tabular}{|c|c|c|c|c|c|}
\hline Variable & Computation & Source & $N$ & Mean & SD \\
\hline Ln employees & Natural logarithm of the total number of employees & Compustat & 588 & 14.2 & 30.0 \\
\hline Sales $(\mathrm{M} \$)$ & Net sales revenue & Compustat & 588 & $3,442.7$ & $6,936.9$ \\
\hline $\begin{array}{l}\text { Advertising expenditure } \\
\text { intensity }\end{array}$ & Advertising expenditures/Sales & Compustat & 588 & 0.03 & 0.08 \\
\hline R\&D expenditure intensity & R\&D expenditures/Sales & Compustat & 588 & 0.02 & 0.08 \\
\hline IT intensity & Total IT\$/Sales & MIT survey & 453 & 0.02 & 0.04 \\
\hline Infrastructure intensity & IT\$ spent on infrastructure/Sales & MIT survey & 346 & 0.009 & 0.011 \\
\hline Transactional IT intensity & IT\$ spent on transactional systems/Sales & MIT survey & 115 & 0.003 & 0.006 \\
\hline Informational IT intensity & IT\$ spent on informational systems/Sales & MIT survey & 119 & 0.004 & 0.009 \\
\hline Strategic IT intensity & IT\$ spent on strategic systems/Sales & MIT survey & 118 & 0.002 & 0.002 \\
\hline Return on assets (\%) & (Income before extraordinary items/Total assets) $* 100$ & Compustat & 564 & 0.54 & 14.1 \\
\hline Tobin's q & $\begin{array}{l}\text { [Market value of common stock + Book value of } \\
\text { debt }+ \text { Book value of preferred stock]/[Book value of } \\
\text { assets and plant, property, and equipment (PPE) } \\
\text { + Estimated replacement cost of PPE] }\end{array}$ & Compustat & 569 & 1.0 & 1.2 \\
\hline Net margin (\%) & (Income before extraordinary items/Total sales) $* 100$ & Compustat & 564 & 1.1 & 13.3 \\
\hline Cost of goods sold & $\begin{array}{l}\text { Cost of merchandise purchased }+ \text { Cost of goods } \\
\text { manufactured for goods sold }\end{array}$ & Compustat & 569 & $2,395.3$ & $5,174.3$ \\
\hline Sales from new products & Sales from new products from the previous year/Total sales & MIT survey & 119 & 0.236 & 0.223 \\
\hline $\begin{array}{l}\text { Sales from modified } \\
\text { products }\end{array}$ & $\begin{array}{l}\text { Sales from products modified or enhanced from } \\
\text { the previous year/Total sales }\end{array}$ & MIT survey & 119 & 0.333 & 0.278 \\
\hline ITC & $\begin{array}{l}\text { A demeaned linear combination of capability variables. } \\
\text { ITC }=((\text { Capability measure } 1-\text { Mean of capability } \\
\text { measure } 1)+\cdots+(\text { Capability measure } 6 \text { - Mean of } \\
\text { capability measure } 6))\end{array}$ & MIT survey & 142 & 0.05 & 1.5 \\
\hline
\end{tabular}

see Breshnahan et al. 2002). We estimate the human resource competency (HR) of firms by assessing (a) the technical and business skills of IT staff, (b) the IT skills of business users, and (c) the relative ability of firms to satisfy their demand for highly skilled IT labor. In addition, senior management championing of IT initiatives is consistently shown to improve the value created by IT investments (Weill 1992, Brynjolffson and Hitt 2000) and disconnects between business units and the IT function typically hinder firms' ability to generate returns from IT (Rockart et al. 1996). Our measure of management competency (MC) therefore assesses both the degree of senior management commitment to IT projects and business unit involvement in IT decisions (Weill and Ross 2004). Table 2 provides qualitative examples of HR and MC found at 7-Eleven Japan.

2.5.2. Practices (Routines). We identified three key organizational practices that support value creation from IT. The first two practices relate to two fundamental activities of IT-enabled organizations-communication and transaction-and the third involves active use of the Internet, one of the most fundamental sociotechnical innovations in recent history.

IT Use Intensity for Communication. Devaraj and Kohli (2003) make a convincing case for the measurement of IT use as a missing link in the relationship between IT investments and firm performance. Brynjolfsson and Yang (1997) also demonstrate that firms using more digital work practices obtain higher performance benefits from their IT investments. We therefore measure the intensity of IT use-both internal and external. Internal IT communication intensity describes the degree to which internal communications and work practices are conducted electronically and measures the use of electronic communication media such as email, intranets, and wireless devices for internal communications. Supplier facing IT communication intensity describes the degree to which information exchanges with suppliers are conducted electronically via email, remote wireless connections, the Internet, and non-Internet electronic data interchange (EDI) connections.

Digital transaction intensity (DT) measures the degree to which both internal and external transactions are conducted electronically. Distinct from internal or external communication intensity, transaction intensity measures the relative digitization of the transactions firms execute with suppliers and customers and is a linear combination of two ratios: electronic purchase orders to total purchase orders and electronic sales to total sales. Process digitization in relationships with suppliers can reduce input costs by reducing procurement time and supply uncertainties that necessitate stockpiles of inventories; it can do this by reducing prices through greater market transparency and by reducing the costs of purchase order and invoice processing. More digital transactions with suppliers can also reduce coordination costs (Malone 1987), transaction costs (Williamson 1975), and agency costs by increasing transparency and mutual monitoring (Jensen and Meckling 1976). Today, firms with more IT capital are smaller (Brynjolfsson et al. 1994) and less vertically integrated (Hitt 1999), indicating that process 
digitization in the supply chain is enabling increased performance by pushing key functions outside the firm boundary. IT also has the potential to transform relationships with customers. Digitization of the customer experience can enable greater customization and a shift from build-to-stock to build-to-order processes, increasing customer satisfaction (Mithas et al. 2005) and reducing the cost of selling (Brynjolfsson and Hitt 2000).

Finally, open Internet architectures can reduce internal and external integration costs. In contrast, proprietary architectures are more complex to connect and maintain, making back-end legacy system integration less efficient. The Internet also allows firms to broaden interactions with customers by collecting systematic data on purchasing decisions and the responsiveness of post-sale customer service operations. The ability to deliver online product support, technical assistance, merchandise tracking, and customer feedback enhances the value of products supported by Internet-based applications (Zhu and Kraemer 2002). We measure the degree to which firms employ Internet architectures in sales force management, employee performance measurement, training, and postsales customer support, all of which were shown to benefit from IT adoption (Brynjolfsson and Hitt 2000, Brynjolfsson 1996) and were important factors in our case studies (see Table 2).

Our case study evidence supports the theoretical conceptualization of IT capabilities as systems of interlocking practices and competencies and demonstrates that investment allocations, driven by strategy, shape and are shaped by firms' practices and skills. For example, we found that informational investments are critical to 7-Eleven Japan's business strategy, which is designed to make stores responsive to even small changes in customer demand and environmental conditions (Nagayama and Weill 2004). 7-Eleven's "total information system" connects 70,000 computers in stores, at headquarters, and at supplier sites, providing transparency across the entire value chain. Recent sales, weather conditions, and product range information are provided graphically to each store to assist in ordering fresh food, which is ordered and delivered three times per day. The result is that on hot days Tokyo's 7-Eleven stores have plenty of cold Bento boxes and on cold days there are lots of hot noodles for sale. The total information system also reduces missed opportunities from out-of-stock items and the need for large inventories, which in Japanese retail are space and cost prohibitive. 7-Eleven CEO Toshifumi Suzuki explains the company's informationintensive strategy: "To produce the best original products with higher quality than any competitors, we continue to create a hypothesis, test it, make another hypothesis, and examine it over and over...." But these organizational practices alone are not enough. 7-Eleven Japan works hard to develop firmwide IT skills and/or "managerial" involvement to enable and reinforce these practices. 7Eleven Japan "counselors" visit each store at least twice a week to work with franchisees to improve their skills in using data from their information systems to manage and order more effectively. Counselors train employees to use point of sale, inventory, and weather-tracking systems to strategically stock and price goods. The point-ofsale and weather-tracking systems are examples of transactional and informational applications that exploit the IT infrastructure. The tight relationship between company counselors and stores increases the IT skills of store operators while reinforcing critical IT practices at the store level, demonstrating the synergy between skills, and IT practices.

7-Eleven Japan's "total information strategy" uses information to make more effective business decisions. The information is extracted and summarized using transactional IT systems that process 35 million sales transactions and 5 million order transactions per day. Each day, these transactions are sent to the 7-Eleven Japan information systems center, where they are integrated, analyzed, and shared, via informational IT, with all store owners and workers at registers in real time. In addition, as CEO Suzuki explains, the business skills of IT employees are critical: "[We] don't rely on the point-of-sale system. IT is merely a tool to achieve business strategy. We shouldn't use the technology unless we can understand what the information means on paper." These examples of human resource competency, management competency, and digital transactions illustrate how organizational IT capabilities support transactional and informational IT assets at 7-Eleven Japan.

Testing Complementarity. Qualitative examples illustrate how IT assets and organizational IT capabilities complement one another in a single firm, but empirical demonstrations of complementarity in larger samples require evidence of the covariance or "clustering" of complementary elements across firms and positive effects of the copresence of complements on performance (Milgrom and Roberts 1990, Bresnahan et al. 2002). We therefore test whether IT assets and organizational capabilities correlate and whether they exhibit reinforcing interaction effects on firm performance (Athey and Stern 1998). If IT investment and organizational IT capabilities are complementary, we expect the following:

HYPOTHESIS 2. Organizational ITC and IT investment intensity are positively correlated.

We also expect that firms with both more IT investments and stronger organizational IT capabilities perform better. Thus:

НYPOTHESIS 3. Variables interacting an aggregate measure of organizational ITC with IT investment intensity by asset class are positively associated with firm performance. 


\subsection{Dependent Variables: Distinguishing Different Dimensions of Firm Performance}

Different assessments of IT value have different theoretical foundations, and empirical results depend heavily on what questions are asked and how data are modeled (Hitt and Brynjolfsson 1996, Kohli and Devaraj 2003). The literature on IT value relates IT investments to a variety of performance measures, including productivity (Brynjolfsson 1996), consumer welfare (Hitt and Brynjolfsson 1996, Brynjolfsson 1996), accounting profit (Weill 1992, Bharadwaj 2000), market valuation (Dos Santos et al. 1993, Bynjolfsson and Yang 1997, Bharadwaj et al. 1999), and operational performance (Barua et al. 1995, Zhu and Kraemer 2002). These performance dimensions are distinct (Hitt and Brynjolfsson 1996) and trade off with each other. Anderson et al. (1997) find that productivity, profitability, and customer satisfaction trade off and that firms' strategies and industries change the nature of the tradeoffs. Quantitative empirical results concerning IT and organizational performance vary in part because measures of performance are multidimensional but measures of IT are typically unidimensional.

To measure associations between IT investments and the performance of firms that are potentially strategically differentiated, we regressed four categories of firm performance-profitability, market valuation, operational performance, and innovation-on total IT intensity, IT intensity by asset class, and the interaction between IT assets and organizational IT capabilities. Profitability is measured by net margin and return on assets (ROA) (Bharadwaj 2000), market valuation by Tobin's q (Hitt and Brynjolfsson 1996, Bharadwaj et al. 1999, Bynjolfsson and Yang 1997), operational performance by the cost of goods sold (Barua et al. 1995, Zhu and Kraemer 2002), and product innovation by revenues from new and modified products.

\section{Methods}

\subsection{Data and Metrics}

Previous researchers have coded types of IT investments according to the language used in media descriptions (Dos Santos et al. 1993); we asked senior IT executives to subdivide their total IT budgets according to descriptions of the asset classes to better understand the management intention for IT investments in each firm. Descriptions of the asset classes and examples of IT assets were used to guide managers in categorizing their IT investments. All 147 respondents were from large, publicly traded U.S. firms, and Compustat was used to obtain performance and other relevant data during 19992002. Our sample is composed of $58 \%$ manufacturing and $42 \%$ services firms, which mirrors the composition of the S\&P 500 and the Fortune 1000. The sample includes 147 firms over 4 years for a panel of 588 firm years between 1999 and 2002, accounting for \$448 billion in output in 2001. The survey instrument was designed and pilot tested as part of the National Science Foundation-funded MIT SeeIT Project. Using the MIT SeeIT instrument, data collection was conducted by Harte Hanks via a random sample of companies in its database, which has been used in previous research (e.g., Brynjolfsson and Hitt 1996). Survey questions and descriptions of the asset classes and capability metrics appear in the appendix. Table 3 provides variable definitions and descriptive statistics.

We used confirmatory factor analysis to validate our grouping of the 18 indicators of ITC into the 6 variables described in $\$ 2.5$. Following Straub (1989), Boudreau et al. (2001), and Zhu and Kraemer (2002), we considered the reliability, content validity, and construct validity of our measures. We tested both the internal consistency and the construct reliability of our IT capability metrics. The average factor loading for indicators used to construct the six capability variables was 0.70 , and all factor loadings were positive, significant, and above the cutoff of 0.4 (Gefen et al. 2000). ${ }^{3}$ The content validity of the instruments was based on a review of the literature, our case studies, and discussions with more than 100 IT managers in a variety of industries at MIT Center for Information Systems Research workshops. Following Straub (1989), we tested the convergent and discriminate validity of our measures to ensure their construct validity. According to the $t$-statistics of individual factor loadings, all independent indicators displayed highly significant contributions to the constructs they were intended to measure, providing confidence in their convergent validity. We tested the discriminate validity of our constructs by analyzing their internal (within measure) and external (across measure) correlations in a correlation matrix containing all independent indicators (Campbell and Fiske 1959, Straub 1989) and found correlations within measures to be higher than correlations across measures in 16 of 18 cases, indicating strong discriminant validity. ${ }^{4}$ The factor loadings and $t$-statistics of convergent validity are reported in Table $4 .^{5}$

\subsection{Reliability of the Data}

We conducted several tests of the reliability of our data. First, as with any self-reported survey data, accuracy depends on the reliability of responses from the IS managers. To improve the accuracy of responses, all surveys were conducted in person or over the telephone, and efforts were made to ensure that respondents were in management positions responsible for IT investments and had detailed knowledge of their firms' IT practices. ${ }^{6}$ Second, in testing for response bias, we found our sample was no different than the largest 3,500 firms in the United States in terms of total output measured by total sales $(t$-statistic $=0.8)$, the number of employees $(t$-statistic $=1.1)$, total advertising expenditures 
Table 4 Reliability and Validity of ITC Metrics

\begin{tabular}{llcc}
\hline $\begin{array}{l}\text { IT capability } \\
\text { metric }\end{array}$ & \multicolumn{1}{c}{ Indicator } & $\begin{array}{c}\text { Factor } \\
\text { loading }\end{array}$ & $\begin{array}{c}\text { Convergent } \\
\text { validity }\end{array}$ \\
\hline $\begin{array}{l}\text { Factor 1: Human } \\
\text { resource capability }\end{array}$ & $\begin{array}{l}\text { Technical skill } \\
\text { Business skill }\end{array}$ & 0.733 & $11.97^{* * *}$ \\
& End user skill & 0.727 & $11.34^{* * *}$ \\
& Labor supply & 0.620 & $10.34^{* * *}$ \\
Factor 3: Internal & Email & 0.742 & - \\
IT use intensity & Intranet & 0.702 & $18.91^{* * *}$ \\
& Wireless & 0.509 & $24.15^{* * *}$ \\
Factor 4: Supplier & Email & 0.731 & - \\
facing IT use & Internet & 0.807 & $12.66^{* * *}$ \\
intensity & EDI & 0.511 & $11.77^{* * *}$ \\
Factor 6: Internet & Sales force mgmt & 0.698 & $11.42^{* * *}$ \\
capability & Performance & 0.769 & $12.30^{* * *}$ \\
& $\quad$ evaluation & & \\
& Training & 0.857 & $15.32^{* * *}$ \\
& Online customer & 0.654 & - \\
\hline & support & & \\
\hline
\end{tabular}

${ }^{* * *} p<0.001$

$(t$-statistic $=0.1)$, total R\&D expenditures $(t$-statistic $=$ $0.9)$, and the cost of goods sold $(t$-statistic $=0.8)$. Also, the performance of firms in our sample (as measured by ROA) does not differ from the population of the 3,500 largest companies $(t$-statistic $=0.5)$, indicating little chance of a systematic response bias along the performance dimension.

\subsection{Control Variables}

Three firm-level variables were used to control for their effects on performance: $R \& D$ expenditure, advertising expenditure, and firm size. Many previous studies demonstrate that $R \& D$ expenditures are strongly correlated with firm performance and are particularly influential in market valuation metrics such as Tobin's q (Montgomery and Wernerfelt 1988, Capon et al. 1990). In addition, advertising expenditures are positively related to firm performance and are associated with market valuation and profitability in particular (Montgomery and Wernerfelt 1988, Capon et al. 1990). ${ }^{7}$ Firm size is controlled for by $\ln$ (employees), and expenditure variables (IT, R\&D, advertising) are operationalized as ratios of expenditures to sales to control for the relative production size of firms. We used industry dummy variables from two-digit standard industry codes (SIC) and separately input the two-digit SIC industry average for each dependent variable into regressions to control for industry-level variation. Both specifications produced similar results for all regressions. We report results based on the second approach to preserve degrees of freedom.

\subsection{Model Specification}

We first tested two model specifications of the relationship between total IT investment intensity and the six performance variables $P_{s}(s=1, \ldots, 6)$ : a fixed-effects model with controls for year and firm effects,

$$
P_{s t}=\alpha+\sum_{i} \beta_{i} \text { Year }_{i}+\beta_{5 s} \mathrm{IT}_{s t}+\varepsilon_{s t},
$$

and an ordinary least squares (OLS) model in each year regressing performance (lagged by one year) on IT intensity (IT), organizational ITC, and the interaction of IT intensity and ITC $($ IT $*$ ITC $):{ }^{8}$

$$
\begin{aligned}
P_{s t}= & \alpha_{s}+\sum_{j} \beta_{s j} C_{j s t}+\beta_{5 s} \mathrm{IT}_{s t-1}+\beta_{6} \mathrm{ITC}_{s} \\
& +\beta_{7}\left(\mathrm{IT}_{s t-1} * \mathrm{ITC}_{s}\right)+\varepsilon_{s t},
\end{aligned}
$$

where $C_{j}(j=1, \ldots, 4)$ represents the three firm-level control variables (ln employees, R\&D intensity, and advertising intensity) and the industry control, and $\varepsilon$ represents the error term.

We then examined relationships between IT investments in each of the four asset classes $\mathrm{AC}_{s k}(s=$ $1, \ldots, 6 ; k=1, \ldots, 4)$ in 2001 and performance in 2001 and 2002 in OLS analysis as follows:

$$
P_{s t}=\alpha_{s}+\sum_{j} \beta_{s j} C_{j s t}+\sum_{k} \beta_{k s} \mathrm{AC}_{s k t-1}+\varepsilon_{s t} .
$$

Finally, having analyzed the contributions of different IT asset classes, we included an interaction term testing the influence of ITC on the performance contributions of each IT asset class:

$$
\begin{aligned}
P_{s t}= & \alpha_{s}+\sum_{j} \beta_{s j} C_{j s t}+\sum_{k} \beta_{k s} \mathrm{AC}_{s k t-1}+\beta_{9 s} \mathrm{ITC}_{s} \\
& +\beta_{10 s}\left(\mathrm{AC}_{s k t-1} * \mathrm{ITC}_{s}\right)+\varepsilon_{s t},
\end{aligned}
$$

where $\mathrm{AC} * \mathrm{ITC}$ represents the term interacting each asset class with the aggregate measure of ITC. We were unable to reject the hypothesis of no heteroscedasticity according to Breusch and Pagan (1979) tests and have reported standard errors according to the White correction (White 1980). We tested for multicollinearity by examining a correlation matrix of all independent variables and discovered no variables entered simultaneously into any regression with a correlation coefficient greater than 0.70 .

\section{Results}

Our results demonstrate that different IT assets are associated with different types of performance benefits for firms that are generally consistent with their strategic goals. For example, strategic IT investments are associated with product innovation (and not with other measures of performance), but only transactional investments are associated with lower costs. These results support Hypothesis 1 and demonstrate that distinct IT assets help explain variation in firm performance. In addition, we find evidence of complementarities between IT 
Table 5 Total IT Intensity, ITC, and Firm Performance

\begin{tabular}{|c|c|c|c|c|c|c|c|c|c|c|}
\hline \multirow[b]{2}{*}{ Specification } & \multicolumn{2}{|c|}{$\mathrm{ROA}$} & \multicolumn{2}{|c|}{ Net margin } & \multicolumn{2}{|c|}{ Tobin's q } & \multicolumn{2}{|c|}{ COGS } & \multirow{2}{*}{$\begin{array}{c}\text { New } \\
\text { products } \\
\text { OLS }\end{array}$} & \multirow{2}{*}{$\begin{array}{c}\text { Modified } \\
\text { products } \\
\text { OLS }\end{array}$} \\
\hline & $\mathrm{FE}$ & OLS & FE & OLS & FE & OLS & $\mathrm{FE}$ & OLS & & \\
\hline Employees & & $\begin{array}{c}-0.72 \\
(0.99)\end{array}$ & & $\begin{array}{c}0.79 \\
(0.69)\end{array}$ & & $\begin{array}{c}0.02 \\
(0.03)\end{array}$ & & $\begin{array}{c}1,722.78^{* * *} \\
(477.99)\end{array}$ & $\begin{array}{c}0.11 \\
(1.03)\end{array}$ & $\begin{array}{c}1.22 \\
(1.55)\end{array}$ \\
\hline$R \& D$ & & $\begin{array}{c}1.02 \\
(1.12)\end{array}$ & & $\begin{array}{c}0.46 \\
(0.65)\end{array}$ & & $\begin{array}{c}-0.06^{* *} \\
(0.02)\end{array}$ & & $\begin{array}{c}99.78 \\
(411.47)\end{array}$ & $\begin{array}{c}-1.90^{* *} \\
(0.88)\end{array}$ & $\begin{array}{l}3.29^{* *} \\
(1.32)\end{array}$ \\
\hline Advertising & & $\begin{array}{c}-1.60 \\
(1.06)\end{array}$ & & $\begin{array}{r}-2.12^{*} \\
(1.23)\end{array}$ & & $\begin{array}{c}0.04 \\
(0.04)\end{array}$ & & $\begin{array}{c}67.22 \\
(316.91)\end{array}$ & $\begin{array}{c}0.30 \\
(1.40)\end{array}$ & $\begin{array}{l}5.60^{* *} \\
(2.38)\end{array}$ \\
\hline Total IT & $\begin{array}{c}-41.77 \\
(36.49)\end{array}$ & $\begin{array}{c}43.76 \\
(47.05)\end{array}$ & $\begin{array}{c}-33.36 \\
(34.95)\end{array}$ & $\begin{array}{c}9.38 \\
(42.29)\end{array}$ & $\begin{array}{c}-1.06 \\
(1.73)\end{array}$ & $\begin{array}{c}-2.05 \\
(1.94)\end{array}$ & $\begin{array}{c}-1,993.8 \\
(2,636.9)\end{array}$ & $\begin{array}{c}-2,133.77 \\
(9,427.10)\end{array}$ & $\begin{array}{c}-44.72 \\
(37.52)\end{array}$ & $\begin{array}{c}-72.62 \\
(52.81)\end{array}$ \\
\hline ITC & & $\begin{array}{c}-2.97 \\
(2.27)\end{array}$ & & $\begin{array}{c}-1.35 \\
(1.95)\end{array}$ & & $\begin{array}{c}0.04 \\
(0.10)\end{array}$ & & $\begin{array}{r}-951.46 \\
(728.72)\end{array}$ & $\begin{array}{c}4.46 \\
(3.81)\end{array}$ & $\begin{array}{c}-1.85 \\
(5.44)\end{array}$ \\
\hline Total IT × ITC & & $\begin{array}{c}9.50 \\
(41.80)\end{array}$ & & $\begin{array}{c}10.28 \\
(36.65)\end{array}$ & & $\begin{array}{c}2.47 \\
(1.76)\end{array}$ & & $\begin{array}{r}-8,299.96 \\
(7,389.96)\end{array}$ & $\begin{array}{c}43.32 \\
(37.86)\end{array}$ & $\begin{array}{l}121.18^{* *} \\
(53.94)\end{array}$ \\
\hline Cons. & $\begin{array}{c}6,731^{* * *} \\
(1,477)\end{array}$ & $\begin{array}{c}1.54 \\
(2.74)\end{array}$ & $\begin{array}{c}5,284^{* * *} \\
(1,413)\end{array}$ & $\begin{array}{c}-0.65 \\
(1.76)\end{array}$ & $\begin{array}{l}187.3^{* *} \\
(69.85)\end{array}$ & $\begin{array}{l}0.68^{* * * *} \\
(0.08)\end{array}$ & $\begin{array}{c}-0.32 \mathrm{e}^{* *} \\
(0.12 \mathrm{e} 6)\end{array}$ & $\begin{array}{c}465.93 \\
(502.18)\end{array}$ & $\begin{array}{c}24.29 \\
(3.47)\end{array}$ & $\begin{array}{l}29.64 \\
(4.31)\end{array}$ \\
\hline $\begin{array}{l}\text { Industry } \\
\text { controls }\end{array}$ & No & Yes & No & Yes & No & Yes & No & Yes & Yes & Yes \\
\hline$R^{2}$ & 0.08 & 0.05 & 0.06 & 0.05 & 0.03 & 0.04 & 0.05 & 0.34 & 0.02 & 0.08 \\
\hline$F$ value & $10.53^{* * *}$ & 0.89 & $7.10^{* * *}$ & 1.02 & $3.59^{* *}$ & 4.27 & $5.45^{* *}$ & $2.26^{* *}$ & $2.71^{* *}$ & $11.85^{* * *}$ \\
\hline Obs. & 375 & 84 & 376 & 84 & 376 & 85 & 373 & 85 & 75 & 74 \\
\hline
\end{tabular}

Notes. FE $=$ fixed effects. Total IT intensity measured at $t-1$ in OLS regressions. Robust standard errors under the White correction are reported.

${ }^{*} p<0.10 ;{ }^{* *} p<0.05 ;{ }^{* *} p<0.001$

assets and organizational IT capabilities. IT assets and ITC covary significantly in our sample, demonstrating that firms with strong ITC demand more IT and vice versa. ITC also displays positive interaction effects with IT assets on a variety of performance measures. Organizational ITCs strengthen the performance effects of IT investments and also broaden their impacts to new dimensions of performance. These results suggest two important extensions to the resource-based theory of IT: a move away from monolithic conceptualizations of IT toward a disaggregated view of IT assets and a view of organizational ITC as a mutually reinforcing system of practices and competencies that both strengthens and broadens the performance impacts of IT.

\subsection{IT Assets and Firm Performance}

We find no association between total IT intensity and firm performance in fixed effects or OLS analyses (see Table 5). These results demonstrate that aggregate IT investments, taken alone, provide little advantage for firms (Bakos 1991, Clemons and Row 1991) and mirror findings that suggest that although total IT capital stock improves firm productivity, it does not contribute to profitability (Hitt and Brynjolfsson 1996). Although ITC enhances the performance effects of total IT investment on all performance dimensions, the interaction effects are not statistically significant except in the analysis of sales from modified products. ${ }^{9}$

Firms in our sample allocate IT investments differently. Manufacturing firms spend $6 \%$ more on IT infrastructure than nonmanufacturing firms, and financial services firms spend $8 \%$ more on strategic, $2 \%$ more on transactional, and $8 \%$ less on informational IT assets than other firms. Significant variation also exists across firms within industries reflecting different strategic choices.

Table 6 reports estimates of relationships between the four IT asset classes in 2001 and firm performance in 2001 and 2002. Infrastructure investments made in 2001 are negatively associated with ROA in 2001 and net margin in 2001 and 2002. However, over time, the negative association with profitability and return diminish. The association between infrastructure investments made in 2001 and ROA in 2002 is positive but not significant, and the loss of net margin is smaller and less significant in 2002. Investments in infrastructure also disrupt short-term efforts at product innovation as measured by revenues from modified products in 2001. The association between infrastructure investments in 2001 and Tobin's q in the same year is positive and significant, indicating a positive relationship between infrastructure investments and market valuation. These findings are consistent with prior research that describes infrastructure investments as disruptive in the short term, producing high up-front implementation and restructuring costs; but these investments are effective in improving business performance in the long term, enabling new applications and reducing long-term costs through integration (Weill and Broadbent 1998, Duncan 1995). 
Table 6 IT Investment Allocations by Asset Class and Firm Performance

\begin{tabular}{|c|c|c|c|c|c|c|c|c|c|c|}
\hline & \multicolumn{2}{|c|}{$\mathrm{ROA}$} & \multicolumn{2}{|c|}{ Net margin } & \multicolumn{2}{|c|}{ Tobin's q } & \multicolumn{2}{|c|}{ COGS } & \multirow{2}{*}{$\begin{array}{c}\text { New } \\
\text { products } \\
2001\end{array}$} & \multirow{2}{*}{$\begin{array}{c}\text { Modified } \\
\text { products } \\
2001\end{array}$} \\
\hline & 2001 & 2002 & 2001 & 2002 & 2001 & 2002 & 2001 & 2002 & & \\
\hline Employees & $\begin{array}{c}0.54 \\
(0.80)\end{array}$ & $\begin{array}{c}-0.495 \\
(1.12)\end{array}$ & $\begin{array}{l}1.01 \\
(0.97)\end{array}$ & $\begin{array}{c}0.94 \\
(0.65)\end{array}$ & $\begin{array}{c}0.001 \\
(0.054)\end{array}$ & $\begin{array}{c}0.002 \\
(0.021)\end{array}$ & $\begin{array}{c}1,493.1^{* *} \\
(503.1)\end{array}$ & $\begin{array}{c}1,623.5^{* * *} \\
(446.4)\end{array}$ & $\begin{array}{c}-1.22 \\
(1.34)\end{array}$ & $\begin{array}{c}-0.127 \\
(1.51)\end{array}$ \\
\hline$R \& D$ & $\begin{array}{c}1.48 \\
(1.72)\end{array}$ & $\begin{array}{c}1.98 \\
(1.27)\end{array}$ & $\begin{array}{c}1.63 \\
(2.18)\end{array}$ & $\begin{array}{c}0.70 \\
(0.60)\end{array}$ & $\begin{array}{c}-0.039 \\
(0.036)\end{array}$ & $\begin{array}{c}-0.066^{* *} \\
(0.024)\end{array}$ & $\begin{array}{c}377.5 \\
(284.2)\end{array}$ & $\begin{array}{l}-116.67 \\
(350.45)\end{array}$ & $\begin{array}{l}-1.74 \\
(0.979)\end{array}$ & $\begin{array}{c}40.61^{* * *} \\
(0.808)\end{array}$ \\
\hline Advertising & $\begin{array}{l}-4.18 \\
(3.84)\end{array}$ & $\begin{array}{c}-2.19^{* *} \\
(0.95)\end{array}$ & $\begin{array}{l}-5.17 \\
(5.31)\end{array}$ & $\begin{array}{c}-2.69^{* *} \\
(1.32)\end{array}$ & $\begin{array}{c}-0.021 \\
(0.061)\end{array}$ & $\begin{array}{c}0.022 \\
(0.041)\end{array}$ & $\begin{array}{c}114.8 \\
(402.4)\end{array}$ & $\begin{array}{c}493.61 \\
(406.99)\end{array}$ & $\begin{array}{c}-0.104 \\
(1.60)\end{array}$ & $\begin{array}{l}5.36^{* * *} \\
(1.52)\end{array}$ \\
\hline \multicolumn{11}{|l|}{ IT variables } \\
\hline Transactional & $\begin{array}{c}273.49 \\
(186.82)\end{array}$ & $\begin{array}{c}-192.08 \\
(212.67)\end{array}$ & $\begin{array}{c}309.77 \\
(201.15)\end{array}$ & $\begin{array}{l}-104.4 \\
(163.79)\end{array}$ & $\begin{array}{l}-5.36 \\
(14.29)\end{array}$ & $\begin{array}{c}-3.02 \\
(9.93)\end{array}$ & $\begin{array}{l}-8,047.5 \\
(82,468)\end{array}$ & $\begin{array}{c}-160,990^{*} \\
(101,138)\end{array}$ & $\begin{array}{c}169.02 \\
(344.58)\end{array}$ & $\begin{array}{c}-836.69 \\
(557.22)\end{array}$ \\
\hline Informational & $\begin{array}{l}313.76 * * \\
(150.98)\end{array}$ & $\begin{array}{c}289.74^{* *} \\
(92.63)\end{array}$ & $\begin{array}{r}269.47^{*} \\
(162.60)\end{array}$ & $\begin{array}{l}167.4^{* *} \\
(76.3)\end{array}$ & $\begin{array}{c}12.00 \\
(10.34)\end{array}$ & $\begin{array}{c}5.08 \\
(5.44)\end{array}$ & $\begin{array}{l}-5,798.5 \\
(22,526)\end{array}$ & $\begin{array}{c}17,651 \\
(28,104)\end{array}$ & $\begin{array}{c}-277.72 \\
(214.26)\end{array}$ & $\begin{array}{r}-1,056.56 \\
(242.11)\end{array}$ \\
\hline Strategic & $\begin{array}{c}46.99 \\
(438.48)\end{array}$ & $\begin{array}{c}117.60 \\
(231.35)\end{array}$ & $\begin{array}{c}332.87 \\
(330.23)\end{array}$ & $\begin{array}{c}338.8 \\
(300.3)\end{array}$ & $\begin{array}{c}-43.49 \\
(37.85)\end{array}$ & $\begin{array}{l}-6.39 \\
(18.54)\end{array}$ & $\begin{array}{c}38,544 \\
(78,713)\end{array}$ & $\begin{array}{c}19,598 \\
(90,352)\end{array}$ & $\begin{array}{r}-620.59 \\
(690.90)\end{array}$ & $\begin{array}{c}2,891.72^{* * *} \\
(905.39)\end{array}$ \\
\hline Infrastructure & $\begin{array}{c}-224.5^{* *} \\
(112.9)\end{array}$ & $\begin{array}{c}74.88 \\
(145.34)\end{array}$ & $\begin{array}{c}-377.59^{* *} \\
(159.98)\end{array}$ & $\begin{array}{r}-179.9^{*} \\
(95.6)\end{array}$ & $\begin{array}{l}16.83^{*} \\
(9.81)\end{array}$ & $\begin{array}{c}-4.24 \\
(4.47)\end{array}$ & $\begin{array}{l}-30,288 \\
(34,889)\end{array}$ & $\begin{array}{c}43,872 \\
(42,782)\end{array}$ & $\begin{array}{c}341.41 \\
(222.58)\end{array}$ & $\begin{array}{l}-48.27^{* * *} \\
(264.77)\end{array}$ \\
\hline $\begin{array}{l}\text { Industry } \\
\text { controls? }\end{array}$ & Yes & Yes & Yes & Yes & Yes & Yes & Yes & Yes & Yes & Yes \\
\hline$R^{2}$ & 0.10 & 0.07 & 0.14 & 0.13 & 0.09 & 0.04 & 0.34 & 0.34 & 0.06 & 0.17 \\
\hline$F$ value & $1.99^{* *}$ & $3.60^{* * *}$ & $1.69^{*}$ & $5.18^{* * *}$ & 1.14 & $2.83^{* *}$ & $2.30^{* *}$ & $2.56^{* *}$ & 1.45 & $14.83^{* * *}$ \\
\hline Obs. & 103 & 95 & 103 & 95 & 104 & 98 & 103 & 98 & 90 & 90 \\
\hline
\end{tabular}

Notes. OLS regressions. Robust standard errors under the White correction are reported.

${ }^{*} p<0.10 ;{ }^{* *} p<0.05 ;{ }^{* *} p<0.001$

Informational investments are positively correlated with ROA and net margin in both 2001 and 2002, demonstrating a positive association with profitability, although the expected association between informational investments and lower costs is not observed. Transactional investments are associated with lower COGS in 2002, supporting the argument that transactional investments reduce costs. Strategic investments are positively associated with revenues from modified products, demonstrating strong support for the association between strategic investments and innovation. As expected, $R \& D$ investment is associated with gains in product innovation but is (unexpectedly) negatively correlated with Tobin's q in 2002. ${ }^{10}$ These results demonstrate that different IT assets produce different types of performance benefits for firms that are consistent with their strategic goals, as outlined in Table 1. Firms with similar levels of total IT intensity allocate investments differently in our data. By disaggregating IT investments, we observe the relative performance effects of different types of IT that may be obscured in total IT investment data.

\subsection{Testing Complementarity Between IT Assets and Organizational IT Capabilities}

Table 7 presents the spearman partial rank order correlations between total IT investment intensity, IT investment intensity by asset class, and ITC, controlling for firm size (see Table 7, row 6). The correlations are all positive and significant, indicating covariance between assets and capabilities. These results support Hypothesis 2-a complementary relationship between ITC and IT investment intensity.

Table 8 presents the results of independent year OLS regressions, assessing the relationships between specific IT assets, ITC, and the interaction between assets and capabilities on performance. ${ }^{11}$

ITC both strengthens the performance effects of IT assets on their primary performance dimensions (those consistent with their strategic purpose) and broadens the impact of IT assets to other performance dimensions. The results for net margin reveal significant positive interaction effects among ITC and transactional investments, informational investments, and strategic investments. The coefficients on strategic and informational investments are also positive and significant, as they were in the regressions of IT investments alone. Infrastructure investments are again negatively associated with profitability, but the interaction effect between infrastructure and ITC is positive and significant on profit, indicating that firms with higher ITC scores achieve gains, not losses, from infrastructure investments. Firms with higher ITC have greater profitability when they invest more in informational, strategic, and infrastructure assets, relative to the average firm. We again find a positive relationship between ROA and informational investments, which reiterates the relationship reported in Table 6 . 
Table 7 Correlations Between IT, Organizational Capabilities, and Performance

\begin{tabular}{|c|c|c|c|c|c|c|c|c|c|c|c|c|}
\hline Measure & 1 & 2 & 3 & 4 & 5 & 6 & 7 & 8 & 9 & 10 & 11 & 12 \\
\hline 1. Total IT & 1.00 & & & & & & & & & & & \\
\hline 2. Infrastructure & $0.83^{* *}$ & 1.00 & & & & & & & & & & \\
\hline 3. Transactional & $0.55^{* *}$ & $0.32^{* *}$ & 1.00 & & & & & & & & & \\
\hline 4. Informational & $0.62^{* *}$ & $0.36^{* *}$ & $0.44^{* *}$ & 1.00 & & & & & & & & \\
\hline 5. Strategic & $0.49^{* *}$ & $0.34^{* *}$ & $0.47^{* *}$ & $0.39^{* *}$ & 1.00 & & & & & & & \\
\hline 6. ITC & $0.33^{* *}$ & $0.27^{* *}$ & $0.22^{* *}$ & $0.30^{* *}$ & $0.33^{* *}$ & 1.00 & & & & & & \\
\hline 7. $\mathrm{ROA}$ & -0.15 & -0.05 & 0.06 & -0.07 & -0.03 & -0.01 & 1.00 & & & & & \\
\hline 8. Net margin & -0.13 & -0.06 & 0.09 & -0.08 & 0.03 & 0.03 & $0.83^{* *}$ & 1.00 & & & & \\
\hline 9. Tobin's q & -0.01 & -0.06 & 0.03 & 0.05 & -0.04 & 0.05 & $0.44^{* *}$ & $0.40^{* *}$ & 1.00 & & & \\
\hline 10. COGS & 0.13 & $0.22^{* *}$ & 0.14 & -0.04 & -0.09 & -0.05 & 0.00 & 0.07 & -0.01 & 1.00 & & \\
\hline 11. Modified products & 0.10 & 0.20 & -0.01 & -0.03 & 0.06 & 0.10 & -0.23 & -0.18 & -0.04 & 0.16 & 1.00 & \\
\hline 12. New products & 0.15 & 0.04 & 0.06 & 0.03 & 0.01 & -0.10 & -0.11 & -0.07 & -0.03 & 0.08 & $0.41^{* *}$ & 1.00 \\
\hline
\end{tabular}

Notes. Spearman partial rank order correlations of total IT spending, IT spending by asset class, organizational ITC in 2001, and performance measures in 2002 controlling for firm size.

${ }^{* *} p<0.05$.

The interaction effect of infrastructure investments and ITC on net margin presents a clear example of the importance of organizational capabilities in explaining variance in the returns to IT investments across firms. For a firm with average organizational capabilities, a $\$ 1$ (sales adjusted) increase in infrastructure investment is associated with a $\$ 366$ decrease in net margin in the following year $(\beta=-365.5)$. For a firm with below-average organizational capabilities (ITC $=-3 ; \sim 2$ standard deviations below the mean), a $\$ 1$ increase in infrastructure investment is associated with an $\$ 820$ decrease in net margin, and for a firm

Table 8 IT Investment Allocations and Interactions with IT Capabilities on Firm Performance

\begin{tabular}{|c|c|c|c|c|c|c|c|c|c|c|}
\hline & \multirow[b]{2}{*}{$R^{2}$} & \multirow[b]{2}{*}{$F$} & \multicolumn{3}{|c|}{$\mathrm{ROA}$} & \multirow[b]{2}{*}{$R^{2}$} & \multirow[b]{2}{*}{$F$} & \multicolumn{3}{|c|}{ Net margin } \\
\hline & & & $\begin{array}{l}\text { Asset } \\
\beta \text { (SE) }\end{array}$ & $\begin{array}{l}\text { ITC } \\
\beta \text { (SE) }\end{array}$ & $\begin{array}{c}\text { Interaction } \\
\beta \text { (SE) }\end{array}$ & & & $\begin{array}{l}\text { Asset } \\
\beta \text { (SE) }\end{array}$ & $\begin{array}{c}\text { ITC } \\
\beta \text { (SE) }\end{array}$ & $\begin{array}{c}\text { Interaction } \\
\beta \text { (SE) }\end{array}$ \\
\hline Transactional $_{t-1} *$ ITC & 0.13 & $3.69^{* * *}$ & $\begin{array}{l}-19.5 \\
(244.5)\end{array}$ & $\begin{array}{c}0.48 \\
(0.63)\end{array}$ & $\begin{array}{c}310.4 \\
(253.8)\end{array}$ & 0.14 & $6.96^{* * *}$ & $\begin{array}{c}86.1 \\
(179.1)\end{array}$ & $\begin{array}{c}1.2 \\
(1.8)\end{array}$ & $\begin{array}{l}348.1^{*} \\
(182.0)\end{array}$ \\
\hline Informational $_{t-1} *$ ITC & 0.13 & $2.79^{* *}$ & $\begin{array}{r}357.8^{*} \\
(211.7)\end{array}$ & $\begin{array}{c}0.21 \\
(0.98)\end{array}$ & $\begin{array}{c}117.9 \\
(239.9)\end{array}$ & 0.15 & $11.3^{* * *}$ & $\begin{array}{l}403.7^{* *} \\
(164.4)\end{array}$ & $\begin{array}{c}1.5 \\
(1.7)\end{array}$ & $\begin{array}{r}353.0^{*} \\
(194.4)\end{array}$ \\
\hline Strategic $_{t-1} *$ ITC & 0.13 & $4.84^{* * *}$ & $\begin{array}{c}31.4 \\
(216.3)\end{array}$ & $\begin{array}{c}0.27 \\
(0.53)\end{array}$ & $\begin{array}{l}244.5 \\
(217.6)\end{array}$ & 0.15 & $7.78^{* * *}$ & $\begin{array}{l}297.5^{* *} \\
(285.6)\end{array}$ & $\begin{array}{c}0.99 \\
(1.7)\end{array}$ & $\begin{array}{l}428.5^{* *} \\
(205.5)\end{array}$ \\
\hline \multirow[t]{2}{*}{ Infrastructure $_{t-1} *$ ITC } & 0.13 & $3.29 * *$ & $\begin{array}{r}3.61 \\
(208.9)\end{array}$ & $\begin{array}{c}0.25 \\
(0.94)\end{array}$ & $\begin{array}{c}55.2 \\
(95.5)\end{array}$ & 0.15 & $6.97^{* * *}$ & $\begin{array}{c}-365.5^{* *} \\
(159.4)\end{array}$ & $\begin{array}{r}0.91 \\
(1.7)\end{array}$ & $\begin{array}{l}151.6^{*} \\
(92.4)\end{array}$ \\
\hline & & & \multicolumn{3}{|c|}{ COGS } & & & \multicolumn{3}{|c|}{ Tobin's q } \\
\hline Transactional $_{t-1} *$ ITC & 0.40 & $2.65^{* *}$ & $\begin{array}{l}-2.2 \mathrm{e} 5^{*} \\
(1.3 \mathrm{e} 5)\end{array}$ & $\begin{array}{c}-1,166.9 \\
(987.0)\end{array}$ & $\begin{array}{l}-0.93 \mathrm{e} 5 \\
(0.65 \mathrm{e} 5)\end{array}$ & 0.06 & $5.54^{* * *}$ & $\begin{array}{l}-0.20 \\
(11.1)\end{array}$ & $\begin{array}{c}0.09 \\
(0.08)\end{array}$ & $\begin{array}{l}18.8^{* *} \\
(8.9)\end{array}$ \\
\hline Informational $_{t-1} *$ ITC & 0.39 & $2.01^{* *}$ & $\begin{array}{c}0.52 \mathrm{e} 5 \\
(0.79 \mathrm{e} 5)\end{array}$ & $\begin{array}{c}-1,186.9 \\
(995.7)\end{array}$ & $\begin{array}{l}0.19 \mathrm{e} 5 \\
(1.0 \mathrm{e} 5)\end{array}$ & 0.04 & $2.36^{* *}$ & $\begin{array}{c}5.02 \\
(10.1)\end{array}$ & $\begin{array}{c}0.09 \\
(0.08)\end{array}$ & $\begin{array}{c}4.23 \\
(12.8)\end{array}$ \\
\hline Strategic $_{t-1} *$ ITC & 0.40 & $2.59^{* *}$ & $\begin{array}{c}-0.35 \mathrm{e} 5 \\
(1.1 \mathrm{e} 5)\end{array}$ & $\begin{array}{l}-1,142.1 \\
(1,002.1)\end{array}$ & $\begin{array}{l}-0.74 \mathrm{e} 5 \\
(0.62 \mathrm{e} 5)\end{array}$ & 0.05 & $3.28^{* *}$ & $\begin{array}{l}-3.4 \\
(18.6)\end{array}$ & $\begin{array}{c}0.08 \\
(0.08)\end{array}$ & $\begin{array}{r}15.4^{*} \\
(8.5)\end{array}$ \\
\hline \multirow[t]{2}{*}{ Infrastructure $_{t-1} *$ ITC } & 0.40 & $3.23^{* *}$ & $\begin{array}{c}1.3 e 5^{*} \\
(0.83 e 5)\end{array}$ & $\begin{array}{l}-999.0 \\
(967.4)\end{array}$ & $\begin{array}{c}-0.78 \mathrm{e} 5^{*} \\
(0.46 \mathrm{e} 5)\end{array}$ & 0.07 & $2.89^{* *}$ & $\begin{array}{r}-4.6 \\
(5.5)\end{array}$ & $\begin{array}{c}0.08 \\
(0.08)\end{array}$ & $\begin{array}{l}8.6^{* *} \\
(3.4)\end{array}$ \\
\hline & & & \multicolumn{3}{|c|}{ Modified products } & & & \multicolumn{3}{|c|}{ New products } \\
\hline Transactional $_{t-1} *$ ITC & 0.29 & $20.79^{* * *}$ & $\begin{array}{r}-525.5 \\
(669.7)\end{array}$ & $\begin{array}{c}-1.3 \\
(1.9)\end{array}$ & $\begin{array}{c}84.2 \\
(661.3)\end{array}$ & 0.09 & $3.24^{* *}$ & $\begin{array}{r}734.2^{*} \\
(369.3)\end{array}$ & $\begin{array}{c}0.76 \\
(1.04)\end{array}$ & $\begin{array}{l}722.2^{* *} \\
(354.9)\end{array}$ \\
\hline Informational $_{t-1} *$ ITC & 0.29 & $21.45^{* * *}$ & $\begin{array}{c}-1,471.3^{* * *} \\
\quad(411.8)\end{array}$ & $\begin{array}{l}-2.9 \\
(2.5)\end{array}$ & $\begin{array}{r}-371.4 \\
(577.2)\end{array}$ & 0.08 & $1.74^{*}$ & $\begin{array}{l}-22.1 \\
(240.9)\end{array}$ & $\begin{array}{c}-1.04 \\
(0.76)\end{array}$ & $\begin{array}{c}468.2 \\
(576.8)\end{array}$ \\
\hline Strategic $_{t-1} *$ ITC & 0.29 & $23.90^{* * *}$ & $\begin{array}{c}3,401.5^{* * *} \\
(802.9)\end{array}$ & $\begin{array}{c}-2.9 \\
(2.5)\end{array}$ & $\begin{array}{c}-371.4 \\
(577.2)\end{array}$ & 0.10 & $4.04^{* * *}$ & $\begin{array}{r}-936.1 \\
(625.9)\end{array}$ & $\begin{array}{c}0.79 \\
(0.92)\end{array}$ & $\begin{array}{c}818.7^{* *} \\
(338.7)\end{array}$ \\
\hline Infrastructure $_{t-1} *$ ITC & 0.29 & $22.32^{* * *}$ & $\begin{array}{c}-482.3 \\
(485.0)\end{array}$ & $\begin{array}{c}-1.5 \\
(2.5)\end{array}$ & $\begin{array}{c}-7.9 \\
(254.6)\end{array}$ & 0.11 & $3.80^{* * * *}$ & $\begin{array}{c}-375.1 \\
(328.8)\end{array}$ & $\begin{array}{l}2.8^{* *} \\
(1.4)\end{array}$ & $\begin{array}{c}422.4^{* *} \\
(152.3)\end{array}$ \\
\hline
\end{tabular}

Notes. OLS regressions with robust standard errors. All control variables and other IT assets are included in regressions but not reported. ${ }^{*} p<0.10 ;{ }^{* *} p<0.05 ;{ }^{* *} p<0.001$ 
with above-average organizational capabilities $($ ITC $=3$; $\sim 2$ standard deviations above the mean), a \$1 increase in infrastructure investment is associated with a $\$ 89$ increase in net margin the year after the investment is made. ${ }^{12}$

The coefficient on transactional investments is again negative and significant on COGS, but the interaction effect, although negative, is not significant. Infrastructure investments have a marginal positive association with COGS, but the interaction effect of infrastructure and ITC is negative and significant on cost. The average firm sees higher short-term costs with more infrastructure investment, but firms with above-average ITC see short-term cost reductions. All else being equal, firms with strong ITC scores are associated with higher market value when they make transactional, infrastructure, and strategic investments, and strong ITC enables greater revenues from new products when transactional, strategic, and infrastructure investment intensities are high. ITC seems to have little enabling effect on revenues from modified products, where informational IT intensities are negative and significant, and strategic IT intensities return strong positive associations, as they had in regressions involving the IT investments alone. We find the inclusion of ITC explains between $2 \%$ and $12 \%$ more performance variance than our models of IT assets alone, as seen in increased $R^{2}$ values in Table 8 compared with Tables 5 and 6.

\subsection{Discussion}

In our data, the average firm experiences performance benefits from investments in different IT assets along dimensions consistent with the strategic purpose of the asset. However, firms with greater ITC experience both stronger performance effects along expected dimensions and a broadening of performance impacts to other measures.

Infrastructure investments produce high up-front implementation and restructuring costs but support future business value by enabling new applications and reducing long-term costs through integration, creating a pattern of lagged benefits (Duncan 1995, Weill and Broadbent 1998, Broadbent et al. 1999). Infrastructure benefits are lagged because new applications that leverage new infrastructure take time to deploy, and important organizational factors mediate their implementation and use. For example, governance structures in most firms separate decision making on applications from decision making on infrastructure, with the former remaining under the authority of the business and the latter with the IT function (Weill and Ross 2004). This organizational separation makes building effective applications on top of new infrastructure challenging. However, firms with strong ITC experience short-term gains, not losses from infrastructure investments, and broaden their performance benefits to include innovation, profit, and lower costs (see Table 8). These firms develop skills and enact practices that enable smoother infrastructure implementations and more effective decision-making processes that govern the integration of infrastructure with new applications. Tight relationships between business units and the IT function (management capabilities-MC), strong cross-functional IT and business skills (human resources capabilities-HRC), and greater digitization of important business processes such as ordering and sales (digital transaction intensity-DT) support integration of infrastructure with new applications and enable firms to more quickly and effectively utilize applications to improve a broader set of performance dimensions beyond market value.

Aggregate measures of IT obscure the performance implications of distinct IT assets. For example, total IT intensity is not correlated with product innovation in our data, but strategic IT investments strongly support innovation, and infrastructure investments are negatively correlated. When evaluated as a monolith, IT seems to have no innovation effect, when in fact different IT assets have conflicting innovation implications. Performance itself is also multidimensional. Firms can pursue different strategies with distinct and at times mutually exclusive performance implications. Cost leadership may be orthogonal to innovation, in terms of both IT investments and performance.

\subsection{Limitations and Future Research}

Although our research opens new avenues for explaining IT value creation from a resource-based perspective, it has some limitations. First, our data set is partly crosssectional, and although we use lagged measures of performance to control for reverse causality, causal claims cannot be made about disaggregated IT assets. However, simultaneity is less likely to bias our results, given that observed performance effects match hypothesized IT assets. A similar defense of causality is used by Bartel et al. (2004), who argue that observation of specific technology impacts on expected performance measures but not on others supports a causal argument (see page 221). Although our data set is the largest we encountered with detailed allocations of IT investments, we did not have enough data to test the long-term effects of IT or to examine path dependencies over time. As infrastructure and strategic assets may impact firm performance years after investments are made, and as IT generally requires periods of learning and adjustment to attain full value, our results may underestimate its effects. In the future, larger longitudinal data sets will be needed to explore causal relationships between IT investment allocations and firm performance (Bharadwaj et al. 1999, p. 1020).

Second, our assessments of organizational capabilities are measured with ordinal self-reported data from a single respondent. These measures are vulnerable to 
respondents' subjective assessments of their organizations and to single respondent bias. More objective measures of organizational capabilities could be collected in future work by logging the dollars spent on technical training, the education and training backgrounds of IT employees, and policies that codify the distribution of decision rights between business units and the IT function.

Third, our division of IT investments into the four asset classes is but one way to characterize firms' investment allocations. Other breakdowns might include aggregations of investments in particular IT projects such as enterprise resource planning (ERP), supply chain management (SCM), or customer relationship management (CRM) projects or other theoretical frameworks distinguishing different types of IT. We hope our work can serve as a useful starting point for these endeavors.

Finally, a natural question emerges from our results: Do certain organizational IT capabilities support certain IT assets in particular? Our work is intended to begin this line of inquiry, yet we examine organizational IT capabilities as a system because of their complementarity as a group of practices and skills. Specific assetcapability synergies could exist, however, and we encourage the investigation of such relationships in future work, although larger data sets will be needed to test such nuanced propositions with sufficient statistical power.

\subsection{Conclusion}

Many researchers have examined the productivity and business value of firm-level IT investments. However, results have varied across performance measures, and significant firm level variation in the returns to IT investments remained unexplained. We complement and extend recent resource-based theories of IT value by unpacking the measurement of "IT" into different asset types that explain additional performance variation. We also find that firms derive greater value per IT dollar by having stronger organizational IT capabilities. These results suggest a move away from monolithic conceptualizations of IT toward a disaggregated view of IT assets and a view of organizational IT capabilities as a mutually reinforcing system of practices and competencies that both strengthens and broadens the performance impacts of IT.

\section{Acknowledgments}

The CISE/IIS/CSS Division of the U.S. National Science Foundation (0085725) and the MIT Center for Information Systems Research supported this research. The authors thank Nils Fondstad, Steve Kahl, George Westerman, seminar participants at Boston University and MIT, the Associate Editor, and three anonymous reviewers for many valuable comments.

\section{Appendix. Definition and Construction of IT Capability Indicators and IT Investment Asset Classes}

\begin{tabular}{|c|c|c|}
\hline Variable & Description & Construction \\
\hline $\begin{array}{l}\text { 1. Human resource } \\
\text { capability }\end{array}$ & $\begin{array}{l}\text { Business skills of IT staff } \\
\text { IT skills of end users } \\
\text { Ability to satisfy demand for } \\
\text { highly skilled IT labor }\end{array}$ & $\begin{array}{l}\text { Given a scale of } 1-5 \text {, with } 1 \text { being "inhibits significantly," } \\
3 \text { being "no effect," and } 5 \text { being "facilitates significantly," } \\
\text { please rate whether the technical skills of IT staff facilitate } \\
\text { or inhibit new technology investments at your company. } \\
\ldots \text { please rate whether the business skills of IT staff facilitate } \\
\text { or inhibit new technology investments at your company. } \\
\text {.. please rate whether the IT skills of end users facilitate } \\
\text { or inhibit new technology investments at your company. } \\
\ldots \text { please rate whether the ability to hire new IT staff facilitates } \\
\text { or inhibits new technology investments at your company. }\end{array}$ \\
\hline $\begin{array}{l}\text { 2. Management } \\
\text { capability }\end{array}$ & $\begin{array}{l}\text { Degree of senior management } \\
\text { commitment to IT projects } \\
\text { Degree of business unit } \\
\text { involvement in IT decisions }\end{array}$ & $\begin{array}{l}\text {... please rate whether the degree of senior management } \\
\text { support for IT projects facilitates or inhibits new } \\
\text { technology investments at your company. } \\
\ldots \text { please rate whether the degree of business unit } \\
\text { involvement in IT projects facilitates or inhibits new } \\
\text { technology investments at your company. }\end{array}$ \\
\hline 3. Internal IT use & $\begin{array}{l}\text { Intensity of electronic } \\
\text { communication media such as } \\
\text { email, intranets, and wireless } \\
\text { devices for internal } \\
\text { communications }\end{array}$ & $\begin{array}{l}\text {... please rate how important the following methods are for } \\
\text { internal communications: (a) email, (b) company } \\
\text { intranets, (c) wireless devices. }\end{array}$ \\
\hline $\begin{array}{l}\text { 4. Supplier facing IT } \\
\text { use }\end{array}$ & $\begin{array}{l}\text { Intensity of electronic } \\
\text { communication media such as } \\
\text { email, intranets, and wireless } \\
\text { devices for communications } \\
\text { with suppliers and supplier } \\
\text { facing work practices }\end{array}$ & $\begin{array}{l}\text {... please rate how important the following methods are for } \\
\text { communications with suppliers: (a) email, (b) company } \\
\text { intranets, (c) wireless devices. }\end{array}$ \\
\hline
\end{tabular}




\section{Appendix (cont'd.)}

\begin{tabular}{|c|c|c|}
\hline Variable & Description & Construction \\
\hline 5. Digital transactions & $\begin{array}{l}\text { Degree of digitization in } \\
\text { purchasing } \\
\text { Degree of digitization in sales } \\
\text { to customers }\end{array}$ & Electronic purchase orders/Total purchase orders \\
\hline 6. Internet capability & $\begin{array}{l}\text { Degree to which firms use } \\
\text { Internet architectures in sales } \\
\text { force management } \\
\text {... in employee performance } \\
\text { measurement } \\
\ldots \text { in training } \\
\text {... in post-sales customer } \\
\text { support }\end{array}$ & $\begin{array}{l}\text { Given a scale of } 1-5 \text {, with } 1 \text { being "no use of the } \\
\text { Internet" and } 5 \text { being "fully automated via the Internet," } \\
\text { please identify to what extent your company uses Internet } \\
\text { technology to perform sales force management. } \\
\text {.. please identify to what extent your company uses Internet } \\
\text { technology to perform employee performance } \\
\text { measurement. } \\
\text {... please identify to what extent your company uses Internet } \\
\text { technology to perform employee training. } \\
\text {.. please identify to what extent your company uses Internet } \\
\text { technology to perform post-sales customer support. }\end{array}$ \\
\hline \multicolumn{3}{|l|}{ IT investment variables } \\
\hline Total IT \$ & \multicolumn{2}{|c|}{$\begin{array}{l}\text { What were the total expenditures on IT in millions of dollars for the entire company, including both } \\
\text { internal and outsourced expenditures? Please assume that IT includes all computers, software, } \\
\text { data communications (including via phone line), and people dedicated to providing IT services. }\end{array}$} \\
\hline Infrastructure & \multicolumn{2}{|c|}{$\begin{array}{l}\text { Of the firmwide IT expenditure identified in Question 2, what percentage would you classify } \\
\text { as IT infrastructure? Please consider IT infrastructure as the base foundation of IT } \\
\text { capability budgeted for and provided by the I/S function and shared across multiple } \\
\text { applications or business units. This infrastructure usually includes the network, help desk, } \\
\text { data centers, etc. but excludes applications. }\end{array}$} \\
\hline Transactional & \multicolumn{2}{|c|}{$\begin{array}{l}\text { Please consider transactional IT as investments in IT made to cut operating costs } \\
\text { (e.g., reduce costs of preparing and sending invoices). }\end{array}$} \\
\hline Informational & \multicolumn{2}{|c|}{$\begin{array}{l}\text {... to provide information. This would include information for accounting, managing quality, } \\
\text { executive information systems, performance management, etc. }\end{array}$} \\
\hline Strategic & \multicolumn{2}{|c|}{$\begin{array}{l}\text {... to increase or protect your sales or market share by providing improved customer } \\
\text { service or products (e.g., online product catalog). }\end{array}$} \\
\hline
\end{tabular}

\section{Endnotes}

${ }^{1}$ The case studies were developed using unstructured and semistructured interviews with upper-level IT management employees, examination of archival data, historical data from the press, and unpublished firm documents, publicly available performance data, and the firms' websites.

${ }^{2}$ Before constructing measures of the practices and capabilities, we asked managers in research workshops to examine our framework to make sure our theory reflected their experiences. Based on these discussions and our case data, we identified 18 indicators of the competencies and practices. Definitions of the variables and their operationalization appear in the appendix. ${ }^{3}$ As our metrics are designed to measure multiple components or dimensions of a construct rather than multiple measures of the same underlying construct, Cronbach's $\alpha$ estimates are less useful in assessing internal consistency. However, $\alpha$ estimates ranged from 0.44 to 0.73 . The alpha for internal IT use intensity was significantly lower than for the rest of our constructs (0.44). This may be because of its considerably high mean (4.4) and low variance (S.D. $=0.8)$, indicating that email intensity was high for most firms in our data set.

${ }^{4}$ External email intensity and internal email intensity were more highly correlated with each other than with their respective constructs (internal IT use intensity and external IT use intensity), indicating that internal and external email use are high for most firms in concert.
${ }^{5}$ Factors 2 (MC) and 5 (DT) are excluded from Table 4 because they are two item factors to which these statistics do not readily apply.

${ }^{6}$ All respondents reported intimate knowledge of their firms' IT practices and close proximity to IT investment decisions. If a respondent was unfamiliar with IT assets and budgeting, the interview was terminated and a replacement respondent was sought. Of respondents, $59 \%$ were the CIO of the firm, $25 \%$ were CTOs, $13 \%$ were IT budget analysts or administrators of IT systems, and 3\% were CFOs.

${ }^{7}$ Not all firms report R\&D and advertising expenditures. After filling in data from other available sources, following Bharadwaj et al. (1999) and Montgomery and Wernerfelt (1988), we input industry average values for each firm for which data remained missing.

${ }^{8} \mathrm{We}$ also tested a pooled OLS model with panel-corrected standard errors, with corrections for both autocorrelation and heteroscedasticity, where the error term was modeled as an AR1 process with $\rho$ diminishing uniformly over time and robust estimation of standard errors. The results were qualitatively unchanged.

${ }^{9} \mathrm{R} \& \mathrm{D}$ intensity is positively associated with product innovation measured by revenue from modified products but negatively associated with revenue from new products. This may indicate that firms in our sample rely more on incremental 
innovation than on discontinuous changes in their product lines (e.g., Nelson and Winter 1982, Tushman and Anderson 1986). ${ }^{10}$ Bharadwaj et al. (1999) also observe the surprising negative association between R\&D investment and Tobin's q. Citing other studies that found the same result, they conclude, "The results are consistent with the findings of prior empirical efforts that attempted to estimate a relationship between [controls for R\&D expenditures] and q" (Bharadwaj et al. 1999, p. 1019). As our coefficient estimates $(-0.066)$ are well within the range of previous estimates $(0.00$ to -0.15$)$, we are satisfied that our results are consistent with prior evidence and reflect the true market value of $R \& D$ capital.

${ }^{11}$ To facilitate more meaningful interpretations, investment intensities and capability metrics were centered and normalized. The results reported are of regressions on dependent variables measured in 2002, one year lagged from observations of investment and capability measures. All control variables and other asset classes are included in the analyses, although their coefficients are not reported. As innovation variables are derived from our survey, we do not have lagged measures of these variables in relation to investments in particular asset classes.

${ }^{12}$ The derivation of these results is as follows: $Y=\alpha+\beta 1 X 1+$ $\beta 2 X 2+\beta 3(X 1 * X 2)+\varepsilon=\alpha+X 1 \beta 2+(\beta 1+X 2 \beta 3) X 1+\varepsilon$. Therefore, the coefficient on $X 1=\beta 1+X 2 \beta 2$.

\section{References}

Anderson, E. W., C. Fornell, R. T. Rust. 1997. Customer satisfaction, productivity, and profitability: Differences between goods and services. Marketing Sci. 16(2) 129-145.

Athey, S., S. Stern. 1998. An empirical framework for testing theories about complementarity in organizational design. NBER Working Paper 6600, Cambridge, MA.

Autor, D., F. Levy, R. Murnane. 1998. Computing inequality: Have computers changed the labor market? Quart. J. Econom. 113(4) $1169-1214$.

Bakos, Y. 1991. A strategic analysis of electronic marketplaces. MIS Quart. 15(3) 295-310.

Barney, J. B. 1991. Firm resources and sustained competitive advantage. J. Management 17(1) 99-120.

Bartel, A., C. Ichniowski, K. Shaw. 2004. Using insider econometrics to study productivity. Amer. Econom. Rev. 2(1) 217-223.

Barua, A., C. H. Kriebel, T. Mukhopadhyay. 1995. Information technology and business value: An analytical and empirical investigation. Inform. Systems Res. 6(1) 2-23.

Bharadwaj, A. S. 2000. A resource-based perspective on IT capability and firm performance: An empirical investigation. MIS Quart. 24(1) 169-196.

Bharadwaj, A. S., S. G. Bharadwaj, B. Konsynski. 1999. Information technology effects on firm performance as measured by Tobin's q. Management Sci. 45(7) 1008-1024.

Boudreau, D., D. Gefen, D. W. Straub. 2001. Validation in MIS research: A state-of-the-art assessment. MIS Quart. 25(1) 1-24.

Bresnahan, T. F., E. Brynjolfsson, L. M. Hitt. 2002. Information technology, workplace organization, and the demand for skilled labor: Firm-level evidence. Quart. J. Econom. 117(1) 339-376.

Breusch, T., A. Pagan. 1979. A simple test for heteroscedasticity and random coefficient variation. Econometrica 47 1287-1294.
Broadbent, M., P. Weill, B. S. Neo. 1999. Strategic context and patterns of IT infrastructure capability. J. Strat. Inform. Sys. 8(2) 157-187.

Brynjolfsson, E. 1996. The contribution of information technology to consumer welfare. Inform. Systems Res. 7(3) 281-300.

Brynjolfsson, E., L. M. Hitt. 1995. Information technology as a factor of production: The role of differences among firms. Econom. Innov. New Tech. 3(4) 183-199.

Brynjolfsson, E., L. M. Hitt. 1996. Paradox lost? Firm-level evidence on the returns to information systems spending. Management Sci. 42(4) 541-558.

Brynjolfsson, E., L. M. Hitt. 2000. Beyond computation: Information technology, organizational transformation and business performance. J. Econom. Perspectives 14(4) 23-48.

Brynjolfsson, E., S. Yang. 1997. The intangible benefits and costs of investments: Evidence from financial markets. J. I. DeGross, K. Kuldeep, eds. Proc. 18th Internat. Conf. Inform. Systems, Association for Information Systems, Atlanta, GA.

Brynjolfsson, E., T. Malone, V. Gurbaxani, A. Kambil. 1994. Does information technology lead to smaller firms? Management Sci. 40(12) 1645-1662.

Campbell, D. T., D. W. Fiske. 1959. Convergent and discriminant validation by the multitrait-multimethod matrix. Psych. Bull. 56(2) 81-105.

Capon, N., J. U. Farley, S. Hoenig. 1990. Determinants of financial performance: A meta analysis. Management Sci. 36(10) 1143-1159.

Clemons, E. K., M. C. Row. 1991. Sustaining IT advantage: The role of structural differences. MIS Quart. 15(3) 275-292.

Cohen, W. M., D. A. Levinthal. 1990. Absorptive capacity: A new perspective on learning and innovation. Admin. Sci. Quart. 35(1) $128-152$.

Devaraj, S., R. Kohli. 2003. Performance impacts of information technology: Is actual use the missing link? Management Sci. 49(3) 273-289.

Dewan, S., C. Min. 1997. The substitution of information technology for other factors of production: A firm level analysis. Management Sci. 43(12) 1660-1675.

Dierickx, I., K. Cool. 1989. Asset stock accumulation and sustainability of competitive advantage. Management Sci. 35(12) $1504-1511$.

Doll, W. J., G. Torkzadeh. 1998. Developing a multidimensional measure of system use in an organizational context. Inform. Management 33(4) 171-185.

Dos Santos, B. L., K. Peffers. 1995. Rewards to investors in innovative information technology applications: First movers and early followers in ATMs. Organ. Sci. 6(3) 241-259.

Dos Santos, B. L., K. Peffers, D. C. Mauer. 1993. The impact of information technology investment announcements on the market value of the firm. Inform. Systems Res. 4(1) 1-23.

Dosi, G., R. Nelson, S. G. Winter. 2000. The Nature and Dynamic of Organizational Capabilities. Oxford University Press, Oxford, UK.

Duncan, N. B. 1995. Capturing flexibility of information technology infrastructure: A study of resource characteristics and their measure. J. Management Inform. Sys. 12(2) 37-57.

Dunne, T., J. Haltiwanger, K. Troske. 1997. Technology and jobs: Secular changes and cyclincal dynamics. Carnegie-Rochester Conf. Series Public Policy XLVI 107-178.

Floyd, S. W., B. Wooldridge. 1990. Path analysis of the relationship between competitive strategy, information technology and financial performance. J. Management Inform. Sys. 7(1) 47-64. 
Gefen, D., D. W. Straub, M. C. Boudreau. 2000. Structural equation modeling and regression: Guidelines for research practice. Comm. AIS 4(7) 1-78.

Goldin, C., L. Katz. 1998. The origins of technology-skill complementarity. Quart. J. Econom. 113(3) 693-732.

Goodhue, D. L., R. L. Thompson. 1995. Task technology fit and individual performance. MIS Quart. 19(2) 213-236.

Grant, R. M. 1996. Toward a knowledge based theory of the firm. Strat. Management J. 17 109-122.

Hitt, L. M. 1999. Information technology and firm boundaries: Evidence from panel data. Inform. Systems Res. 10(2) 134-149.

Hitt, L. M., E. Brynjolfsson. 1996. Productivity, business profitability, and consumer surplus: Three different measures of information technology value. MIS Quart. 20(2) 121-142.

Jensen, M. C., W. H. Meckling. 1976. Theory of the firm: Managerial behavior, agency costs, and ownership structure. J. Financial Econom. 3 295-316.

Keen, P. G. W. 1991. Shaping the Future: Business Design Through Information Technology. Harvard Business School Press, Cambridge, MA.

Kelley, M. R. 1994. Productivity and information technology: The elusive connection. Management Sci. 40(11) 1406-1425.

Kohli, R., S. Devaraj. 2003. Measuring information technology payoff: A meta-analysis of structural variables in firm-level empirical research. Inform. Systems Res. 14(2) 127-145.

Kreuger, A. 1993. How computers have changed the wage structure: Evidence from micro data. Quart. J. Econom. 108(1) 33-60.

Loveman, G. W. 1994. An assessment of the productivity impact of information technologies. T. J. Allen, M. S. Scott Morton, eds. Information Technology and the Corporation of the 1990s: Research Studies. MIT Press, Cambridge, MA.

Malone, T. W., J. Yates, R. I. Benjamin. 1987. Electronic markets and electronic hierarchies. Comm. ACM 30(6) 484-497.

Mata, F. J., W. L. Fuerst, J. Barney. 1995. Information technology and sustained competitive advantage: A resource-based analysis. MIS Quart. 19(4) 487-505.

Milgrom, P., J. Roberts. 1990. The economics of modern manufacturing: Technology, strategy and organization. Amer. Econom. Rev. 80(3) 511-528.

Mithas, S., M. S. Krishnan, C. Fornell. 2005. Why do customer relationship management applications affect customer satisfaction? J. Marketing. 69(4) 201-209.

Montgomery, C., B. Wernerfelt. 1988. Diversification, Ricardian rents, and Tobin's q. RAND J. Econom. 19 623-632.

Nagayama, K., P. Weill. 2004. 7-Eleven Japan Co., Ltd.: Reinventing the retail business model. Center for Information Systems Research Working Paper 338, Sloan School of Management, MIT, Cambridge, MA.
Nelson, R., S. Winter. 1982. An Evolutionary Theory of Economic Change. Harvard University Press, Cambridge, MA.

Prahalad, C. K., G. Hamel. 1990. The core competence of the corporation. Harvard Bus. Rev. 63 79-91.

Richardson, G. B. 1972. The organization of industry. Econom. J. 82 883-896.

Rockart, J. F., M. J. Earl, J. Ross. 1996. Eight imperatives for the new IT organization. Sloan Management Rev. 38(1) 43-55.

Ross, J. W., C. M. Beath, D. L. Goodhue. 1996. Develop long term competitiveness through IT assets. Sloan Management Rev. 38(1) 31-45.

Sambamurthy, V., A. Bharadwaj, V. Grover. 2003. Shaping agility through digital options: Reconceptualizing the role of IT in contemporary firms. MIS Quart. 27(2) 237-263.

Strassman, P. 1990. The Business Value of Computers. Information Economics Press, New Haven, CT.

Straub, D. W. 1989. Validating instruments in MIS research. MIS Quart. 13(2) 147-169.

Teece, D. J., G. Pisano, A. Shuen. 1997. Dynamic capabilities and strategic management. Strat. Management J. 18(7) 509-533.

Tushman, M. L., P. Anderson. 1986. Technological discontinuities and organizational environments. Admin. Sci. Quart. 31(3) 439-465.

Wade, M., J. Hulland. 2004. Review: The resource-based view and information systems research: Review, extension, and suggestions for future research. MIS Quart. 28(1) 107-142.

Weill, P. 1992. The relationship between investment in information technology and firm performance: A study of the valve manufacturing sector. Inform. Systems Res. 3(4) 307-333.

Weill, P., S. Aral. 2005. IT savvy: Achieving industry leading returns from your IT portfolio. CISR Res. Briefing 5(2A) 1-4.

Weill, P., M. Broadbent. 1998. Levering the New Infrastructure: How Market Leaders Capitalize on Information Technology. Harvard Business School Press, Cambridge, MA.

Weill, P., J. Ross. 2004. IT Governance: How Top Performers Manage IT Decision Rights for Superior Results. Harvard Business School Press, Cambridge, MA.

Wernerfelt, B. 1984. A resource based view of the firm. Strat. Management J. 5 171-180.

White, H. 1980. A heteroscedasticity-consistent covariance matrix estimator and a direct test for heteroscedasticity. Econometrica 48(4) 817-838.

Williamson, O. 1975. Markets and Hierarchy: Analysis and Antitrust Implications. Free Press, New York.

Zhu, K., K. L. Kraemer. 2002. e-Commerce metrics for net-enhanced organizations: Assessing the value of e-commerce to firm performance in the manufacturing sector. Inform. Systems Res. 13(3) 275-295. 